\title{
Conceptual design of a Ca-Cu chemical looping process for hydrogen production in integrated steelworks
}

\author{
J. R. Fernández ${ }^{1 *}$, I. Martínez ${ }^{2}$, J. C. Abanades ${ }^{1}$, M.C. Romano ${ }^{2}$ \\ ${ }^{1}$ Spanish Research Council, CSIC-INCAR. C/ Francisco Pintado Fe, 26, 33011, Oviedo, \\ Spain \\ ${ }^{2}$ Politecnico di Milano, Department of Energy, Via Lambruschini 4, 20156 Milano, Italy \\ *Corresponding author: José Ramón Fernández, jramon@incar.csic.es, Telephone:+34 \\ 985119090, Fax:+34 985297662
}

\begin{abstract}
A novel configuration of the $\mathrm{Ca}-\mathrm{Cu}$ looping process is proposed for the production of a $\mathrm{H}_{2}$-enriched fuel gas from blast furnace gas (BFG). $\mathrm{CO}$ from $\mathrm{BFG}$ is converted with $\mathrm{H}_{2} \mathrm{O}$ to $\mathrm{CO}_{2}$ and $\mathrm{H}_{2}$ in a sorption enhanced water gas shift (SEWGS) stage where $\mathrm{CO}_{2}$ is simultaneously removed from the gas using a $\mathrm{CaO}$-based sorbent. $\mathrm{A} \mathrm{Cu} / \mathrm{CuO}$ chemical loop supplies the energy required for the regeneration of the $\mathrm{CaO}$ carbonated during the SEWGS via the exothermic reduction of $\mathrm{CuO}$ with coke oven gas (GOG) (and/or other $\mathrm{N}_{2}$-free off-gas from the steel mill). The resulting $\mathrm{Ca}-\mathrm{Cu}$ looping process comprises three reaction stages: SEWGS, $\mathrm{Cu}$ oxidation, and a simultaneous $\mathrm{CuO}$ reduction $/ \mathrm{CaCO}_{3}$ calcination stages. These are carried out in an arrangement of interconnected fluidizedbed reactors operating at atmospheric pressure. The use of fluidized beds facilitates the feed of a continuous make-up flow of limestone (precursor of the $\mathrm{CaO}$ needed for the $\mathrm{CO}_{2}$ capture) and the generation of the associated purge of $\mathrm{CaO}$ needed in the steel mill. Moreover, this configuration allows for a solids' segregation step to be introduced, which improves the energy performance of the process since the $\mathrm{Cu}$-based solids would act as thermal ballast in the SEWGS reactor. A conceptual design of this process is presented for a set of boundary conditions in order to demonstrate the theoretical feasibility of the process and to find the operational window that will ensure optimal performance in terms of energy and $\mathrm{CO}_{2}$ capture efficiency. A reference case is analyzed in more detail by assuming that the SEWGS is carried out at $600{ }^{\circ} \mathrm{C}$ and the regeneration of the sorbent is carried out at $870{ }^{\circ} \mathrm{C}$ using as fuel gas the coke oven gas (COG) from the steel mill. Considering sub-stoichiometric conditions in the oxidation stage to limit the maximum temperature at $900{ }^{\circ} \mathrm{C}, 27 \%$ of the $\mathrm{BFG}$ can be decarbonized in the SEWGS reactor producing $110 \mathrm{Nm}^{3}$ of $\mathrm{H}_{2}$ per tonne of steel. Under these conditions, a $\mathrm{CO}_{2}$ capture ratio of $31 \%$ with respect to the total carbon emissions in the steel mill can be achieved. Apart from the $\mathrm{H}_{2}$ produced, more than $60 \%$ of the thermal input of the $\mathrm{Ca}-\mathrm{Cu}$ process ends as high temperature heat generated in the SEWGS reactor and as sensible heat in the exhaust gases that could be efficiently recovered by producing high pressure steam to generate electricity in the steel mill power plant.
\end{abstract}


Keywords: Hydrogen, steelworks, $\mathrm{CO}_{2}$ capture, sorption enhanced water gas shift, chemical looping combustion

\section{Introduction}

A drastic reduction in anthropogenic $\mathrm{CO}_{2}$ emissions is needed before 2050 in order to achieve the climate change mitigation targets [1] that have been set as long term objectives after COP21. The iron and steel industry is the largest energy consuming manufacturing sector worldwide and contributes about 5-7\% of the total anthropogenic $\mathrm{CO}_{2}$ emissions [2]. Modern steelworks have been highly optimized and today they are being operated very close to their thermodynamic limits in terms of carbon use. It is therefore extremely difficult to further reduce $\mathrm{CO}_{2}$ emissions as they are inherently linked to the extensive use of carbon containing fuels in the different parts of the iron and steel making process [3]. $\mathrm{CO}_{2}$ Capture and Storage (CCS) can lead to a drastic reduction in $\mathrm{CO}_{2}$ emissions far beyond that currently achievable in the steelmaking industry $[1,3]$. In this field, significant R\&D initiatives are ongoing in Europe through the Ultra-Low $\mathrm{CO}_{2}$ Steelmaking (ULCOS) project $[4,5]$ and in Japan through the COURSE50 project $[4,6]$. The conventional post-combustion capture amine-based chemical absorption technologies are in principle suitable for the capture of $\mathrm{CO}_{2}$ from steel mills [2, 7]. However, the varying characteristics (e. g. composition, flowrate and location) of the different off-gases generated across the multiple parts of the iron and steelmaking process make it difficult to install capture systems aimed at a high reduction of $\mathrm{CO}_{2}$ emissions [8,9]. Moreover, if the steel mill off-gases are used in a combined cycle for high efficiency power generation, a low amount of low pressure steam is available for solvent regeneration from the power plant and limited $\mathrm{CO}_{2}$ capture efficiencies can be achieved while keeping high thermodynamic efficiency [10].

The implementation of pre-combustion capture systems on the blast furnace gas (BFG) appears to be an attractive option to achieve higher carbon capture rates in the steelmaking process [11], since BFG contains $60-80 \%$ of the total carbon entering the steel mill in the form of $\mathrm{CO}$ and $\mathrm{CO}_{2}$ [2-4]. At the same time, a decarbonized $\mathrm{H}_{2}$ enriched fuel gas is produced suitable for use in the power plant and in the main process heaters (hot stoves and coke plant). Among the pre-combustion $\mathrm{CO}_{2}$ capture processes, the Sorption Enhanced Water Gas Shift (SEWGS) [12] seems to be particularly suitable for application in steel mills $[10,13]$ and it is the subject of the ongoing EU demonstration project STEPWISE [14]. In SEWGS processes, almost pure hydrogen is produced from $\mathrm{CO}$ and $\mathrm{H}_{2} \mathrm{O}$ through the water gas shift reaction, while the $\mathrm{CO}_{2}$ is removed from the gas phase as soon as it is produced [15]. So far, this concept has been envisaged to be mainly implemented in a system of multiple fixed beds operating in parallel that remove the $\mathrm{CO}_{2}$ at high temperature (up to $550^{\circ} \mathrm{C}$ ) and pressure (up to 30 bar) [15-18]. The sorbent usually proposed for the $\mathrm{CO}_{2}$ capture in the SEWGS process is hydrotalcite-based clay, which also acts as water-gas-shift catalyst, being regenerated either by a thermal-swing technique or by reducing the pressure and purging with steam $[16,18]$. 
Calcium-based materials have also been widely proposed in the literature as $\mathrm{CO}_{2}$ sorbent [19-21] for enhancing the thermodynamics of catalytic processes aimed at $\mathrm{H}_{2}$ production from methane (Sorption Enhanced Reforming, SER) [22-24] or from syngas (SEWGS) $[13,25,26]$. These solids can be obtained from a wide range of abundant, natural and inexpensive sources, such as limestone or dolomite and their presence in SER and SEWGS processes minimizes coke formation and diminishes the steam requirements [23]. When $\mathrm{CO}_{2}$ is captured using these materials, $\mathrm{CaCO}_{3}$ is formed and its subsequent regeneration demands temperatures around $900{ }^{\circ} \mathrm{C}$. The calcination of $\mathrm{CaCO}_{3}$ is highly endothermic and needs to be carried out under a $\mathrm{CO}_{2}$-rich atmosphere if the process is aimed at very low $\mathrm{CO}_{2}$ emissions (i.e. in order to generate a rich stream of $\mathrm{CO}_{2}$ suitable for purification, compression and storage).

Different alternatives have been proposed in the literature as a means of providing the large amount of heat required for the calcination of $\mathrm{CaCO}_{3}$ in pre-combustion capture SER/SEWGS and in post-combustion capture Calcium looping systems. This heat can be directly supplied using an oxy-combustion system [27-30], indirectly through high temperature heat transfer surfaces [31-34] or by the direct contact with hot solids from an air-blow combustion chamber [35-37]. Another alternative is to use a chemical looping combustion (CLC) system, typically proposed for the $\mathrm{CO}_{2}$ capture in power generation [38], in which oxygen is transferred from air to the fuel by using an oxygen carrier (typically a metal oxide) [39]. This avoids the dilution by nitrogen of the combustion products and generates a gas highly concentrated in $\mathrm{CO}_{2}$, making the $\mathrm{CO}_{2}$ capture easier and cost-effective [40]. The CLC concept was adapted to form part of the "unmixed reforming" concept [41], in which the exothermic oxidation of $\mathrm{Ni}$ with air supplies the energy required for the decomposition of $\mathrm{CaCO}_{3}$, thereby regenerating the Ca-based sorbent needed for the next cycle. Carrying out simultaneously both oxidation and calcination reactions in one single stage allows a higher energy efficiency to be achieved as the heat is directly transferred from the oxygen carrier to the calcium carbonate. However, the $\mathrm{CO}_{2}$ generated in the calcination with this system is emitted highly diluted with $\mathrm{N}_{2}$, which means that $\mathrm{CO}_{2}$ capture is not feasible without further separation steps [42]. Recent CLC configurations have been proposed to calcine $\mathrm{CaCO}_{3}$ so that the $\mathrm{CO}_{2}$ capture can be carried out by means of indirect heating using the high heat-transfer capacity of $\mathrm{NiO}$ [43] or iron oxides [44] that come from an oxidation step at temperatures above $1000^{\circ} \mathrm{C}$.

A $\mathrm{Ca}-\mathrm{Cu}$ chemical looping process was recently proposed [45] for enhancing the production of $\mathrm{H}_{2}$ with $\mathrm{CO}_{2}$ capture, in which the heat needed for calcination is supplied by the exothermic reduction of $\mathrm{CuO}$ to $\mathrm{Cu}$ with a gaseous fuel. The theoretical advantages of such combined chemical loops are similar to those of "unmixed reforming" processes, i.e. there is no need for heat transfer surfaces in the reactors, as the heat for the $\mathrm{CaCO}_{3}$ calcination is supplied in situ by the exothermic heat of $\mathrm{CuO}$ reduction. However, the key difference is that in the $\mathrm{Ca}-\mathrm{Cu}$ processes the $\mathrm{CO}_{2}$ released during calcination of $\mathrm{CaCO}_{3}$ is not diluted with $\mathrm{N}_{2}$ but generated in a concentrated stream of $\mathrm{CO}_{2}$ and $\mathrm{H}_{2} \mathrm{O}_{(\mathrm{v})}$, which are the reaction products of reducing $\mathrm{CuO}$ with a 
suitable gaseous fuel. A variety of experimental demonstrations using high-performance materials with direct application to the $\mathrm{Ca}-\mathrm{Cu}$ looping process have been reported in recent years [46-53]. To date, most of works investigating the $\mathrm{Ca}-\mathrm{Cu}$ looping process have been focused on developing systems composed of fixed-bed reactors [54-64]. A considerable progress has been made recently in the study of CLC systems in fixed beds [65-69]. These configurations facilitate the performance at high pressure, which allows higher energy efficiencies to be achieved [70] and avoid the need of downstream solidgas separation devices [40]. However, CLC fixed-bed systems require adequate heat management strategies in order to avoid hot spots and approach the complete conversion of gases and solids [71, 72]. Moreover, several reactors performing in parallel that need a large number of high-temperature valves are needed to ensure a continuous operation [58, 73]. Detailed model simulations including the thermal integration of the $\mathrm{Ca}-\mathrm{Cu}$ looping process on a large scale have demonstrated the feasibility of this process for $\mathrm{H}_{2}$ production $[58,62]$ and for power generation [57] with competitive efficiency penalties with respect to NGCC systems without capture. Other application of the $\mathrm{Ca}-\mathrm{Cu}$ chemical loop in post-combustion capture systems has also been assessed [74], although the use of significant amount of methane in the fuel reactor, ultimately converted with an efficiency typical of a steam cycle instead that of a combined cycle, will most probably prevent this application from being competitive against other capture technologies suited for natural gas.

This work proposes a novel $\mathrm{Ca}-\mathrm{Cu}$ process scheme for the production of a $\mathrm{H}_{2}$-enriched fuel gas of direct use in a steel mill or elsewhere via the SEWGS of blast furnace gas (BFG) with integrated $\mathrm{CO}_{2}$ capture by $\mathrm{CaO}$. The $\mathrm{Cu} / \mathrm{CuO}$ chemical loop allows the calcium-based sorbent carbonated in the SEWGS stage and the limestone required for steel production to be calcined in a rich atmosphere of $\mathrm{CO}_{2}$ using coke oven gas (COG) and/or other $\mathrm{N}_{2}$-free off-gases available in the steel mill. The process is carried out in an arrangement of fluidized-bed reactors, in which a solids segregation step is introduced in order to obtain separately the $\mathrm{CaO}$ required for the ironmaking process and to improve the performance of the process since the copper-based particles would act as thermal ballast in the SEWGS stage, as explained below. This novel configuration has been envisaged to reach a substantial reduction of carbon emissions in the steelmaking process if the rich streams of $\mathrm{CO}_{2}$ generated in the process are purified and safely stored. A full conceptual design of the $\mathrm{Ca}-\mathrm{Cu}$ looping process is presented in this work for a set of boundary conditions that will allow its application in a representative steel mill. Reasonable assumptions concerning the reactions involved in each stage of the process have been made using literature data on similar chemical looping combustion and calcium looping systems. A sensitivity analysis of the main operating parameters has been carried out to demonstrate the theoretical viability of the process and to determine the operational window that will ensure optimal performance in terms of energy and $\mathrm{CO}_{2}$ capture efficiency.

\section{Process description}


The $\mathrm{Ca}-\mathrm{Cu}$ looping process proposed in this work for the $\mathrm{CO}_{2}$ capture from blast furnace gas $(\mathrm{BFG})$ comprises three main reaction stages, i.e. the sorption enhanced water gas shift (SEWGS) of $\mathrm{BFG}$, the simultaneous $\mathrm{CuO}$ reduction/ $\mathrm{CaCO}_{3}$ calcination with a gaseous fuel and the oxidation of $\mathrm{Cu}$ with air. The general process scheme, which is presented in Figure 1, mainly consists of three interconnected fluidized-bed reactors operating at atmospheric pressure. The choice of fluidized beds in this application is based on the need to handle a continuous make-up flow of limestone (which is the precursor of the $\mathrm{CaO}$ needed for the reaction stage involving $\mathrm{CO}_{2}$ capture by carbonation) and generate the associated purge of the $\mathrm{CaO}$-rich material needed in the steel mill. These Ca flows will also allow the renovation of solids that may have been deactivated by impurities in the raw fuel gases coming from the steel mill (BFG, COG, etc). Most of the CLC systems proposed in the literature [40] are carried out in arrangements of fluidized-bed reactors, which allow for a good contact between gases and solids and facilitate the transport of the solids between the stages of the process. The $\mathrm{CO}_{2}$ capture by means of calcium looping has also been shown to be feasible in interconnected fluidized beds for pre-combustion [75-77] and post-combustion [78-82] applications. Moreover, this configuration avoids the need for switching hightemperature valves (that are typically required for SER and CLC systems with fixed beds), facilitates suitable $\mathrm{Cu} / \mathrm{Ca}$ ratios for the different reaction stages and allows the introduction of a solids separation step by segregation between the dense $\mathrm{Cu}$-rich solids and the Ca-rich particles, as explained below.

In the first stage of the proposed process, a low pressure $\mathrm{H}_{2} / \mathrm{N}_{2}$ fuel gas (stream 2) is produced through the sorption enhanced water gas shift (SEWGS) from a low calorific value and carbon-rich blast furnace gas (BFG) (stream 1) in the presence of $\mathrm{CaO}$, which acts as $\mathrm{CO}_{2}$ sorbent. This stage is expected to operate at around $600^{\circ} \mathrm{C}$. Under these conditions, both WGS (Eq. 1) and carbonation (Eq. 2) reactions are highly favoured, so that the almost complete conversion of $\mathrm{CO}$ and $\mathrm{H}_{2} \mathrm{O}$ to $\mathrm{CO}_{2}$ and $\mathrm{H}_{2}$ can be expected, with a substantial $\mathrm{CO}_{2}$ removal from the gas phase (in situ as soon as it is formed).

$$
\begin{array}{ll}
\mathrm{CO}(\mathrm{g})+\mathrm{H}_{2} \mathrm{O}(\mathrm{g}) \leftrightarrows \mathrm{CO}_{2}(\mathrm{~g})+\mathrm{H}_{2}(\mathrm{~g}) & \Delta \mathrm{H}_{298 \mathrm{~K}}=-41 \mathrm{~kJ} / \mathrm{mol} \\
\mathrm{CaO}(\mathrm{s})+\mathrm{CO}_{2}(\mathrm{~g}) \leftrightarrows \mathrm{CaCO}_{3}(\mathrm{~s}) & \Delta \mathrm{H}_{298 \mathrm{~K}}=-178.8 \mathrm{~kJ} / \mathrm{mol}
\end{array}
$$

The product gas will contain around 30-35\% vol. of $\mathrm{H}_{2}$ on a dry basis (depending on the $\mathrm{N}_{2}$ content of the BFG) and less than $1 \%$ vol. of $\mathrm{CO}$ and $\mathrm{CO}_{2}$. This decarbonized $\mathrm{H}_{2}$ enriched fuel gas, with an improved heating value with respect to the original $\mathrm{BFG}$, can be used to provide heat for the steel mill processes (i. e., coke oven, stoves, boilers, etc, as it is done today with existing carbon-rich fuel gases), for power generation in a combined cycle after compression, or to produce steel through a Direct Reduced Iron (DRI) process avoiding the need for a dedicated steam reforming (FTR) plant [83]. Both the WGS and carbonation reactions are highly exothermic, so the excess in high temperature heat from the SEWGS stage can be efficiently used to produce steam for the steam cycle, that is typically employed in integrated steel mills for power generation. 
After being separated from the product gas in a downstream cyclone, the carbonated particles are preheated by direct contact with hot process gases and sent to a second fluidized bed (the fuel reactor and calciner) where the regeneration of the $\mathrm{CO}_{2}$ sorbent occurs. The heat required for the calcination is supplied by the exothermic reduction of a CuO-based material using any " $\mathrm{N}_{2}$ free" fuel gas containing $\mathrm{CH}_{4}$ (Eq. 3), $\mathrm{CO}$ (Eq. 4) or $\mathrm{H}_{2}$ (Eq. 5), (stream 8 in Figure 1). Low calorific value fuel gases generated across the iron and steelmaking process, such as the Coke Oven Gas (COG) or the Basic Oxygen Furnace Gas (BOFG), which contain significant amounts of $\mathrm{CH}_{4}, \mathrm{H}_{2}$ and $\mathrm{CO}$, being almost free of $\mathrm{N}_{2}$ (see Table 1), are suitable for this operation. Natural gas can be also supplied to the fuel reactor/calciner to increase the amount of BFG that can be processed in the SEWGS. The typical temperatures required for the calcination of $\mathrm{CaCO}_{3}$ (between $860^{\circ} \mathrm{C}$ and $900^{\circ} \mathrm{C}$ depending on the $\mathrm{CO}_{2}$ content in the product gas [84]) match very well with the optimal operating temperature of fuel reactors of Copper-based CLC systems [40].

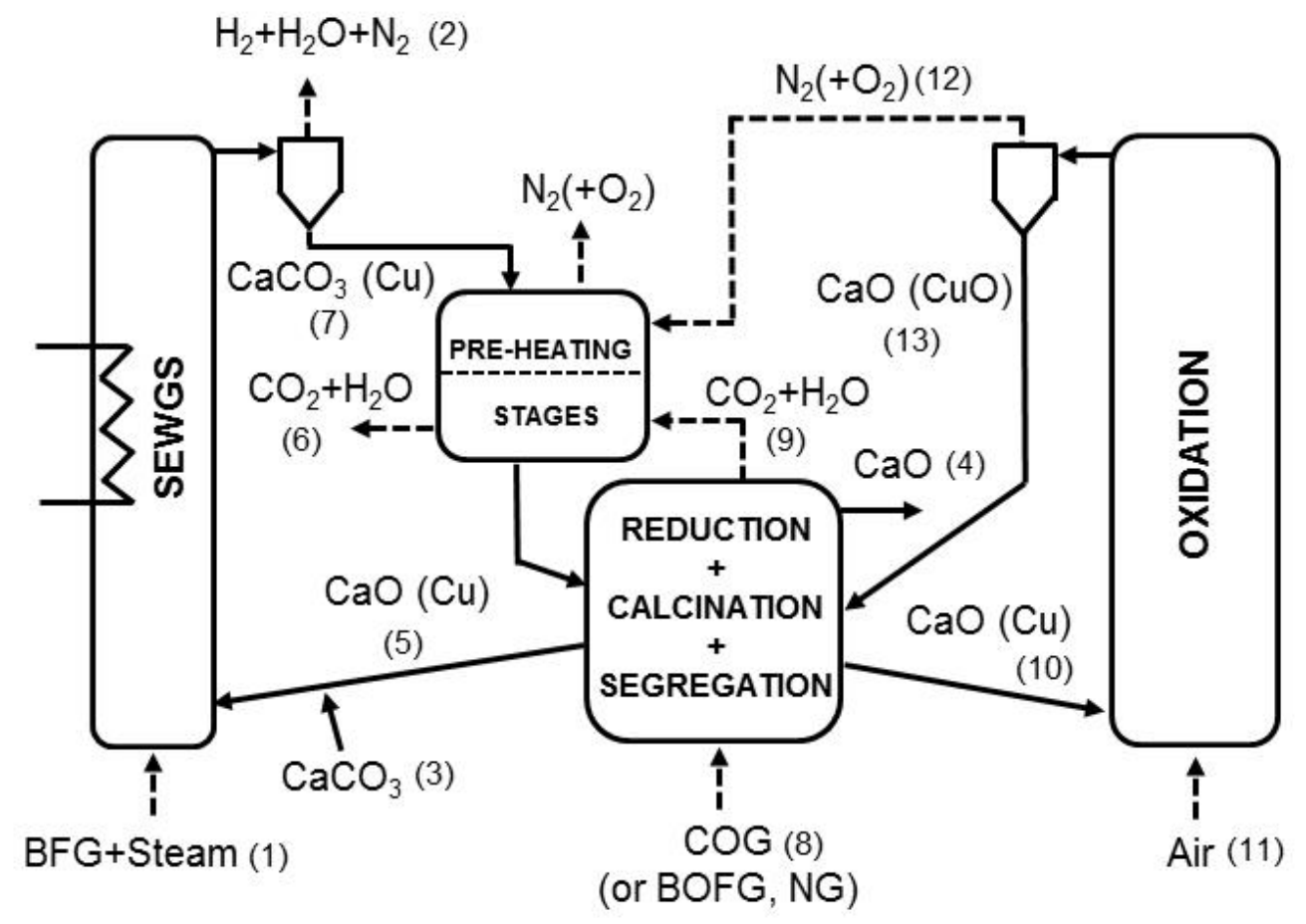

Figure 1. Scheme of the novel $\mathrm{Ca}-\mathrm{Cu}$ looping process proposed for the $\mathrm{CO}_{2}$ capture from blast furnace gas using fuel gases from steel mills.

The product gas (stream 9 in Figure 1) will be mainly composed of the $\mathrm{CO}_{2}$ released from the $\mathrm{CaCO}_{3}$ calcination and the $\mathrm{CO}_{2}$ and $\mathrm{H}_{2} \mathrm{O}$ resulting from the reduction of $\mathrm{CuO}$ with the fuel gas. To achieve a complete reduction of the copper oxide to $\mathrm{Cu}$ in a wellmixed fluidized bed, complete fuel oxidation cannot be achieved and low amounts of unburnt compounds resulting from the incomplete oxidation of the fuel gases will also be present in stream 9. In this case, as proposed for other CLC systems [40], an additional oxygen polishing step to complete the combustion of the non-converted compounds to $\mathrm{CO}_{2}$ and $\mathrm{H}_{2} \mathrm{O}$ or a low temperature $\mathrm{CO}_{2}$ purification unit would be required in order to obtain a final concentrated stream of $\mathrm{CO}_{2}$ and to recover the 
unconverted fuel gases. Alternatively, a complete fuel oxidation may be achieved by accepting an incomplete copper oxide reduction in the fuel reactor/calciner.

$$
\begin{array}{ll}
4 \mathrm{CuO}(\mathrm{s})+\mathrm{CH}_{4}(\mathrm{~g}) \rightarrow 4 \mathrm{Cu}(\mathrm{s})+\mathrm{CO}_{2}(\mathrm{~g})+2 \mathrm{H}_{2} \mathrm{O}(\mathrm{g}) & \Delta \mathrm{H}_{298 \mathrm{~K}}=-195.3 \mathrm{~kJ} / \mathrm{mol} \\
\mathrm{CuO}(\mathrm{s})+\mathrm{CO}(\mathrm{g}) \rightarrow \mathrm{Cu}(\mathrm{s})+\mathrm{CO}_{2}(\mathrm{~g}) & \Delta \mathrm{H}_{298 \mathrm{~K}}=-131.9 \mathrm{~kJ} / \mathrm{mol} \\
\mathrm{CuO}(\mathrm{s})+\mathrm{H}_{2}(\mathrm{~g}) \rightarrow \mathrm{Cu}(\mathrm{s})+\mathrm{H}_{2} \mathrm{O}(\mathrm{g}) & \Delta \mathrm{H}_{298 \mathrm{~K}}=-89.6 \mathrm{~kJ} / \mathrm{mol}
\end{array}
$$

The $\mathrm{CaCO}_{3}$ required in the ironmaking process (around $280 \mathrm{~kg} \mathrm{CaCO}_{3}$ per tonne of steel [4]) can be fed into the system as make-up (stream 3 in Figure 1) to be calcined in the fuel reactor calciner without generating a separate source of $\mathrm{CO}_{2}$ emission. From a thermodynamic point of view, the $\mathrm{CaCO}_{3}$ make-up should be fed after preheating. While solids can be preheated downstream the SEWGS reactor in a gas-solid contactor such as a moving bed or a cyclone preheating tower typical of cement plants, part of the solids preheating may be performed by feeding the fresh $\mathrm{CaCO}_{3}$ to the SEWGS reactor as illustrated in Figure 1, by exploiting the reaction heat of the WGS and carbonation reactions. The reduction of steam generated in the SEWGS reactor is more than balanced by the corresponding fuel saving in the fuel reactor/calciner per unit of hydrogen produced in the SEWGS assuming the limestone were fed to the calciner at lower temperature.

The separation of the solids by segregation, even if it is uncomplete, highly improves the energy performance of the process, since $\mathrm{Cu}$ solids would act as thermal ballast in the SEWGS reactor and the $\mathrm{Cu}$ fraction still oxidized at calciner outlet would oxidize part of the hydrogen produced in the same reactor. Perfect segregation between solids is challenging in continuous systems because axial concentration profiles appear when fluidising mixtures with very different particle properties [85]. However complete segregation is not necessary before the SEWGS, since the presence of $\mathrm{Cu}$ may be needed to catalyse the water gas shift reaction in addition to the $\mathrm{CaO}$ [86], which is the main reacting solid. Segregation is also very important to separate the lime required for the ironmaking process (virtually pure $\mathrm{CaO}$ ) at the fuel reactor calciner outlet (see Figure 1). The ratios of solids densities and/or particle sizes are the main factors to achieve an effective separation of the solids by segregation [85, 87]. This is a similar operation to that envisaged for carbon strippers under study in other CLC systems with solid fuels to separate unconverted char from the oxygen carrier [40]. Under suitable fluidization conditions, very high separation efficiencies can be achieved (up to $95 \%$, comparable to those obtained in CLC carbon strippers [40]), since the $\mathrm{CaO}$ particles (porous solids with an apparent density of around $1800 \mathrm{~kg} / \mathrm{m}^{3}$ ) will tend to rise, while the denser $\mathrm{Cu}$-based particles (with an apparent density of around $3000-3500 \mathrm{~kg} / \mathrm{m}^{3}$ ) will sink in the reactor. Downstream of the fuel reactor calciner, the solid stream directed to a third fluidized bed (air reactor) for its subsequent oxidation (stream 10) is allowed to contain a fraction of $\mathrm{CaO}$, since this material will simply be recirculated through the air reactor, which performs at relatively mild temperatures, avoiding $\mathrm{CaO}$ deactivation. 
Most of the solids from the calciner are sent to the air reactor, which operates as a circulating fluidized-bed (CFB). Air is fed into this reactor to oxidise the $\mathrm{Cu}$-based material that will be subsequently used in the fuel reactor calciner as heat source for calcination (stream 13 in Figure 1). In principle, the oxidation can be carried out with excess of oxygen (i.e., achieving complete oxidation of $\mathrm{Cu}$ into $\mathrm{CuO}$ in this reactor) or at under-stoichiometric conditions (i.e., without complete oxidation of $\mathrm{Cu}$ ). Therefore, depending on the air-to- $\mathrm{Cu}$ ratio in the air reactor, the $\mathrm{Cu}$-based material can be oxidised to $\mathrm{Cu}_{2} \mathrm{O}$ or to $\mathrm{CuO}$, Eq. (6) and Eq. (7). In any case, the oxidation reactor operates adiabatically, limiting the operating temperature to around $900^{\circ} \mathrm{C}$ in order to avoid loss of activity by sintering and/or agglomeration of both calcium and $\mathrm{Cu}$-based materials. Cu-based materials with very high active content (higher than $60 \mathrm{wt} . \%$ ) have been proven to be resistant to deactivation and agglomeration in long duration cyclic tests carried out at temperatures around $900{ }^{\circ} \mathrm{C}$ [88-90]. Several works have also demonstrated that calcination temperatures below $950{ }^{\circ} \mathrm{C}$ do not cause significant deactivation on Ca-based materials compared to the effect of carbonation/calcination cycles in the long term $[91,92]$. The $\mathrm{O}_{2}$-depleted air released at very high temperature from the air reactor (stream 12 in Figure 1) is a high-quality source of thermal power that can be used for preheating requirements and/or for producing high pressure steam that can be used for power generation in a steam cycle. After the separation of the solids from the product gas in a cyclone, they are fed into the fuel reactor calciner (stream 13) to complete the cyclic operation.

$$
\begin{array}{ll}
4 \mathrm{Cu}(\mathrm{s})+\mathrm{O}_{2}(\mathrm{~g}) \rightarrow 2 \mathrm{Cu}_{2} \mathrm{O}(\mathrm{s}) & \Delta \mathrm{H}_{298 \mathrm{~K}}=-359.7 \mathrm{~kJ} / \mathrm{mol} \mathrm{O}_{2} \\
2 \mathrm{Cu}_{2} \mathrm{O}(\mathrm{s})+\mathrm{O}_{2}(\mathrm{~g}) \rightarrow 4 \mathrm{CuO}(\mathrm{s}) & \Delta \mathrm{H}_{298 \mathrm{~K}}=-284.4 \mathrm{~kJ} / \mathrm{mol} \mathrm{O}_{2}
\end{array}
$$

\section{Process modelling assumptions}

Mass and energy balances involved at every stage of the proposed $\mathrm{Ca}-\mathrm{Cu}$ chemical looping system have been solved using an in-house code GS developed at the Department of Energy of the Politecnico di Milano [93]. A reference case study has been analyzed to assess the performance of the proposed concept as well as to demonstrate its potential for being integrated in steelworks. Moreover, a sensitivity analysis of the key design variables has been carried out to determine the operational window that leads to optimal performance in terms of energy consumption and $\mathrm{CO}_{2}$ capture efficiency. Balances have been solved taking as reference 1 tonne of steel produced in the integrated steel mill. Flow rates and the composition of the gas streams (i.e. $\mathrm{BFG}, \mathrm{COG}$ and $\mathrm{BOFG}$ ) coming from the steelworks have been taken from the reference BF-BOF based integrated steel mill balances reported by the IEA in [4]. In this reference plant, approximately $1609 \mathrm{Nm}^{3}$ of blast furnace gas (BFG), $179 \mathrm{Nm}^{3}$ of coke oven gas (COG) and $88 \mathrm{Nm}^{3}$ of basic oxygen furnace gas (BOFG) are produced from the main stages of the iron and steelmaking process [4]. The composition of these steel mill off-gases are listed in Table 1 . Regarding the solids, about $20 \%$ of the Cabased material is assumed to be converted to $\mathrm{CaCO}_{3}$ in the SEWGS reactor and the $\mathrm{Cu}-$ based solids consist of 60 wt.\% of $\mathrm{CuO}$ over alumina. The relatively high $\mathrm{CaO}$ capacity 
is justified by the high make-up flow of fresh limestone fed into the process, which results in a very active sorbent circulating through the SEWGS reactor (e.g. according to the definition proposed by [94] a maximum average $\mathrm{CaO}$ conversion of around 27-29 $\%$ should result for the conditions of this work). The main reference plant assumptions adopted in this study are summarized in Table 2.

Table 1. Composition and lower calorific value (LHV) of the main off-gases from the integrated steel mill used for the calculations [4].

\begin{tabular}{|c|c|c|c|}
\hline & $\begin{array}{c}\text { Blast Furnace } \\
\text { Gas (BFG) }\end{array}$ & $\begin{array}{c}\text { Coke Oven } \\
\text { Gas (COG) }\end{array}$ & $\begin{array}{c}\text { Basic Oxygen Furnace } \\
\text { Gas (BOFG) }\end{array}$ \\
\hline Composition (\%vol) & \multicolumn{3}{|c|}{} \\
\hline $\mathrm{CH}_{4}$ & -- & 23.0 & -- \\
\hline Other HC & -- & 2.7 & 56.9 \\
\hline $\mathrm{CO}$ & 22.3 & 3.8 & 14.4 \\
\hline $\mathrm{CO}_{2}$ & 22.1 & 1.0 & 2.6 \\
\hline $\mathrm{H}_{2}$ & 3.6 & 59.5 & 12.2 \\
\hline $\mathrm{H}_{2} \mathrm{O}$ & 3.2 & 4.0 & 13.8 \\
\hline $\mathrm{N}_{2}$ & 48.8 & 5.8 & -- \\
\hline $\mathrm{O}_{2}$ & -- & 0.2 & 7.47 \\
\hline LHV $\left[{\left.\mathrm{MJ} / \mathrm{Nm}^{3}\right]}\right.$ & 3.21 & 17.33 & \\
\hline
\end{tabular}

Table 2. Operating conditions of the $\mathrm{Ca}-\mathrm{Cu}$ looping process in the reference case study.

\begin{tabular}{|c|c|}
\hline Parameters & $\begin{array}{l}\text { Reference } \\
\text { values }\end{array}$ \\
\hline Temperature in SEWGS, ${ }^{\circ} \mathrm{C}$ & 600 \\
\hline $\mathrm{S} / \mathrm{C}$ molar ratio in SEWGS & 1 \\
\hline Temperature of inlet gases in SEWGS, ${ }^{\circ} \mathrm{C}$ & 250 \\
\hline Temperature in Fuel Reactor, ${ }^{\circ} \mathrm{C}$ & 870 \\
\hline Temperature of fuel gas at Fuel Reactor inlet, ${ }^{\circ} \mathrm{C}$ & 600 \\
\hline Temperature in Air Reactor, ${ }^{\circ} \mathrm{C}$ & 900 \\
\hline Temperature of inlet air in Air Reactor, ${ }^{\circ} \mathrm{C}$ & 300 \\
\hline Molar Cu-to-CaO ratio in the SEWGS reactor & 0.03 \\
\hline Molar $\mathrm{Cu}$-to- $\mathrm{CaO}$ ratio in the air reactor & 0.03 \\
\hline $\mathrm{CaCO}_{3} / \mathrm{Ca}$ at $\mathrm{SEWGS}$ outlet & 0.20 \\
\hline Molar $\mathrm{Cu}_{2} \mathrm{O} / \mathrm{Cu}$ ratio at Fuel Reactor outlet & 0.045 \\
\hline
\end{tabular}

\section{Results}

4.1. General discussion on the mass and energy balances of the $\mathrm{Ca}-\mathrm{Cu}$ chemical loop 
In this section possible operating windows for the two chemical loops used in the process are examined. The main process variables of the SEWGS reactor are the temperature and the steam to carbon ratio. In Figure 2 and Figure 3, the effect of these parameters on syngas composition and $\mathrm{CO}_{2}$ capture efficiency is shown, on the basis of equilibrium calculations. The optimal operating conditions in view of these results should be defined on the basis of an economic trade-off between $\mathrm{CO}_{2}$ capture efficiency (favored by a low temperature and a high $\mathrm{S} / \mathrm{C}$ ratio), thermodynamic efficiency (favored by the opposite conditions) and reaction kinetics. From the results obtained, the assumed SEWGS operating temperature of $600^{\circ} \mathrm{C}$ and $\mathrm{S} / \mathrm{C}=1$ must be reasonably close to an economic optimum because they allow $\mathrm{CO}_{2}$ capture efficiency from the BFG of about $95 \%$ with moderate steam consumption and at a temperature where both WGS and $\mathrm{CaO}$ carbonation are known to be sufficiently fast [13, 86, 95].

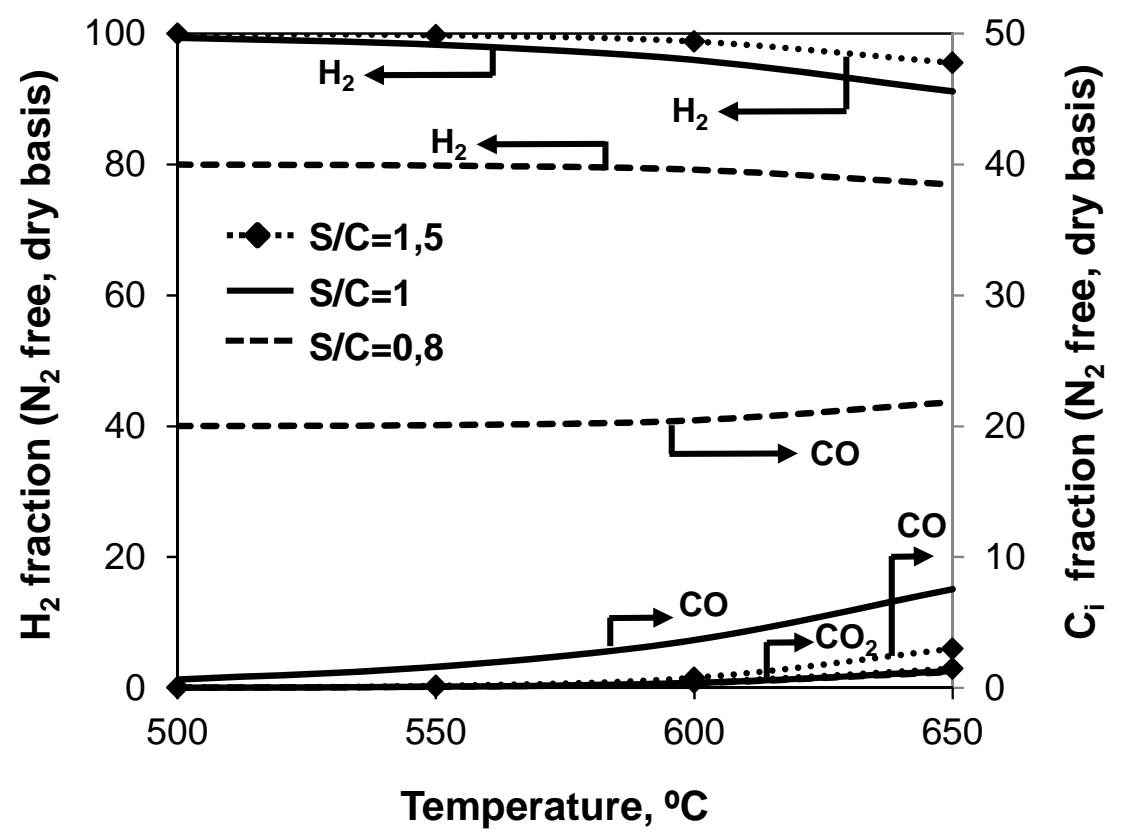

Figure 2. Effect of temperature and steam-to-carbon ratio on SEWGS equilibrium (at atmospheric pressure). 


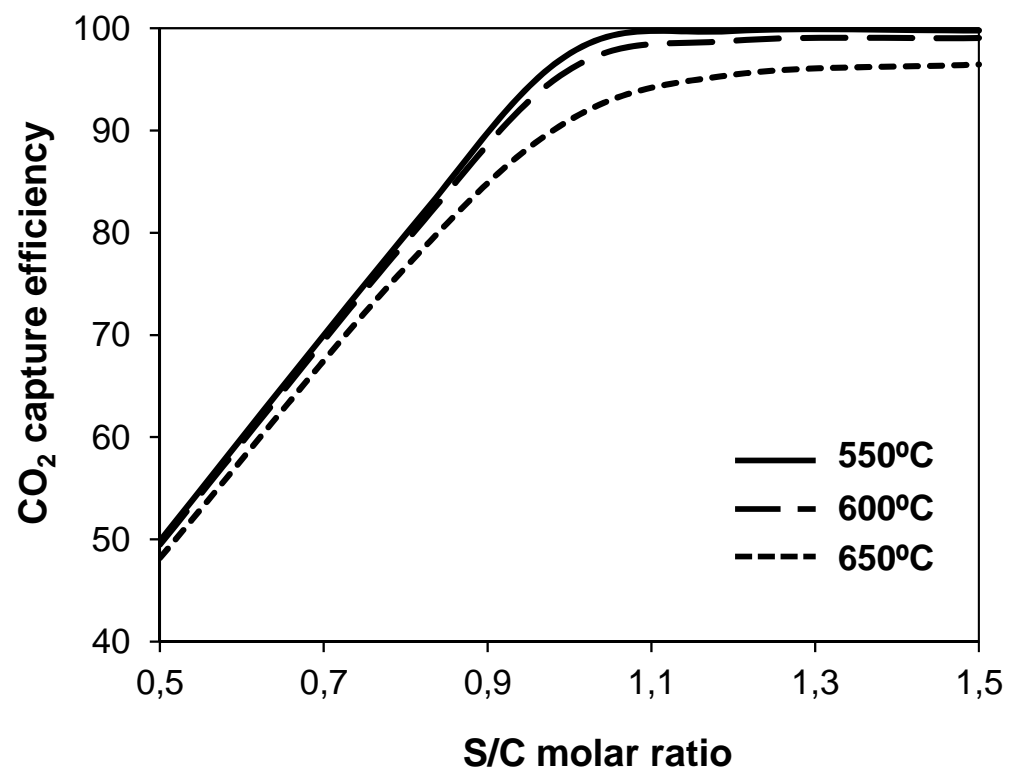

Figure 3. $\mathrm{CO}_{2}$ capture efficiency on SEWGS equilibrium as a function of the steam-tocarbon ratio and temperature.

In the case of the CLC loop, an initial analysis can be based on the effect of the air-to$\mathrm{Cu}$ ratio in the air reactor, for different solids compositions (determined by the $\mathrm{Cu} / \mathrm{CaO}$ ratio). The amount of oxygen supplied to the air reactor (air-to-Cu ratio) and the inert content (here represented by the $\mathrm{CaO}$ in addition to the oxygen carrier support $\mathrm{Al}_{2} \mathrm{O}_{3}$ ) in the inlet solids stream affects the proportion of $\mathrm{Cu} / \mathrm{Cu}_{2} \mathrm{O} / \mathrm{CuO}$ formed during the oxidation as well as the maximum temperature achieved in the air reactor. In Figure 4, the oxidation temperature (i.e. temperature at the adiabatic air reactor outlet) as a function of the air-to- $\mathrm{Cu}$ mass ratio at the inlet of this reactor for two different solid compositions is shown, assuming completely reduced Copper at the reactor inlet. As can be seen in Figure 4, the temperature achieved during $\mathrm{Cu}$ oxidation initially increases as the air-to- $\mathrm{Cu}$ ratio increases, as a consequence of the exothermicity of the oxidation reaction. For a sub-stoichiometric air-to-Cu ratio, the amount of air is not enough to oxidize $\mathrm{Cu}$ to $\mathrm{CuO}$ completely. For a low air-to- $\mathrm{Cu}$ ratio $\left(\mathrm{O}_{2} / \mathrm{Cu}\right.$ below about $1 / 4$ on a mole basis) a mixture of $\mathrm{Cu} / \mathrm{Cu}_{2} \mathrm{O}$ is obtained at the air reactor outlet. For an intermediate air-to- $\mathrm{Cu}$ ratio $\left(\mathrm{O}_{2} / \mathrm{Cu}\right.$ between about $1 / 4$ and $\left.1 / 2\right)$, after all the copper has been oxidized to $\mathrm{Cu}_{2} \mathrm{O}$, fully oxidized $\mathrm{CuO}$ starts to form and a $\mathrm{Cu}_{2} \mathrm{O} / \mathrm{CuO}$ mixture is obtained in the solids population. In this zone, the temperature increases with the air/ $\mathrm{Cu}$ ratio with a different slope. This is due to the different reaction enthalpies for the oxidation reactions (Eq. 6 and Eq. 7). Figure 4 also shows a discontinuity when passing from the $\mathrm{Cu}-\mathrm{Cu}_{2} \mathrm{O}$ system to the $\mathrm{Cu}_{2} \mathrm{O}-\mathrm{CuO}$ one, due to the fact that $\mathrm{CuO}$ starts to form when the $\mathrm{O}_{2}$ partial pressure in the gas phase is sufficiently high. For example, considering the $\mathrm{Cu} / \mathrm{CaO}=0.03$ line, $\mathrm{Cu}$ is completely converted to $\mathrm{Cu}_{2} \mathrm{O}$ for an air-to- $\mathrm{Cu}$ mass ratio of 0.55 . At this condition, the temperature in the reactor is $905^{\circ} \mathrm{C}$ and the corresponding $\mathrm{O}_{2}$ partial pressure in the gas phase, which is determined by the $\mathrm{Cu} / \mathrm{CuO} / \mathrm{O}_{2}$ equilibrium, is 0.0004 bar. At this temperature, the equilibrium $\mathrm{O}_{2}$ partial pressure for the $\mathrm{Cu}_{2} \mathrm{O} / \mathrm{CuO} / \mathrm{O}_{2}$ system is 0.02 bar. Therefore, some additional non- 
reacting air has to be added to reach such $\mathrm{O}_{2}$ partial pressure and to allow $\mathrm{CuO}$ formation. This inert air addition causes the small temperature drop visible in the figure, due to the sensible heat required to heat the inlet air at $300^{\circ} \mathrm{C}$ up to the reactor temperature. The observed discontinuity is larger at higher temperatures because the $\mathrm{Cu}_{2} \mathrm{O} / \mathrm{CuO} / \mathrm{O}_{2}$ and $\mathrm{Cu} / \mathrm{CuO} / \mathrm{O}_{2}$ equilibria involve higher $\mathrm{O}_{2}$ partial pressure difference when the temperature increases [40]. The maximum temperature at air reactor outlet is achieved when $\mathrm{Cu}$ is fully oxidized to $\mathrm{CuO}$, which occurs with different air-to- $\mathrm{Cu}$ ratio, based again on the equilibrium of the $\mathrm{Cu}_{2} \mathrm{O} / \mathrm{CuO} / \mathrm{O}_{2}$ system. The maximum temperature achievable also depends on the amount of inert solids in the system. The lower the amount of inert species, the higher the temperature (i.e. with higher $\mathrm{Cu} / \mathrm{Ca}$ ratio in this case). After the maximum temperature has been reached, temperature falls as the air-to$\mathrm{Cu}$ ratio increases, due to the increased thermal ballast of the excess air used. In light of this behavior, we can expected the targeted oxidation temperature in the air reactor to be achieved either by using a sub-stoichiometric (i.e. involving incomplete $\mathrm{Cu}$ oxidation) or an over-stoichiometric air/Cu ratio.

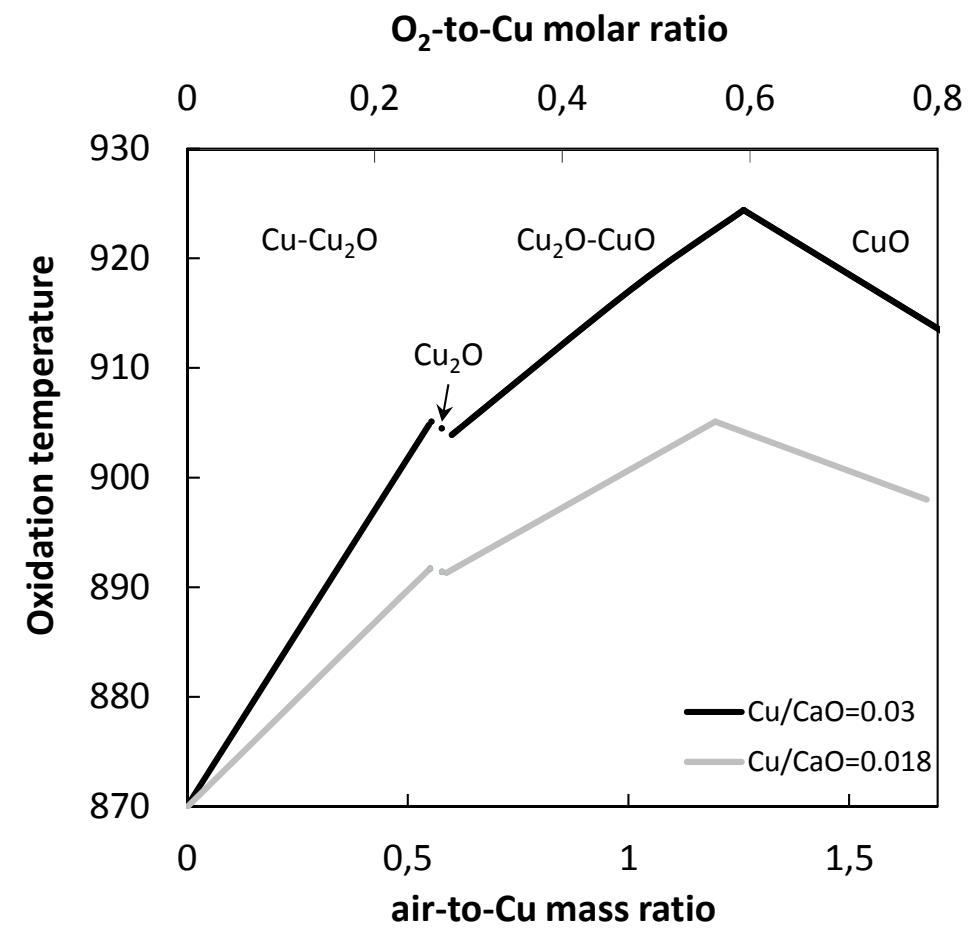

Figure 4. Effect of the air-to- $\mathrm{Cu}$ mass ratio and $\mathrm{Cu}$-to-CaO molar ratio at the air reactor inlet on the oxidation temperature. $\mathrm{Cu} / \mathrm{CaO}$ ratio of 0.03 corresponds to a solid stream flowing to the air reactor containing $3.2 \%$ wt. of $\mathrm{Cu}$, whereas a $\mathrm{Cu} / \mathrm{CaO}$ ratio of 0.018 corresponds to a $\mathrm{Cu}$ content of $2.0 \% \mathrm{wt}$.

In Figure 5, the heat provided to the fuel reactor/calciner per kmol of $\mathrm{H}_{2}$ consumed as well as the solids circulation in the air reactor are shown for the assumed reference reactor temperatures and assuming complete reduction of the oxygen carrier. For each solids composition, the amount of air used in the air reactor (and therefore the composition of the copper-based solids at the fuel reactor/calciner inlet) is determined to 
reach $900^{\circ} \mathrm{C}$ at the air reactor outlet at sub-stoichiometric and over-stoichiometric proportions (black and grey lines, respectively). On the left-hand side of the graph, the minimum amount of $\mathrm{Cu}$ in the solids can be appreciated. This amount corresponds to $1.5 \%$ of $\mathrm{Cu}$, which depends greatly on the specific operating conditions assumed for the calculations (e.g. reactor temperatures, gas temperatures at the reactor inlets, $\mathrm{Cu}$ oxidation level at the air reactor inlet, amount of $\mathrm{Al}_{2} \mathrm{O}_{3}$ support in the oxygen carrier). This minimum $\mathrm{Cu}$ content corresponds to those conditions where the oxygen carrier has been fully oxidized to $\mathrm{CuO}$ in the air reactor so as to reach the desired temperature. Therefore, when operating at this condition of minimum $\mathrm{Cu}$ content, operating the air reactor either at sub-stoichiometric or over-stoichiometric air-to- $\mathrm{Cu}$ proportions result in the same amount of sensible and reaction heat provided in the fuel reactor/calciner. Starting from this point, when the $\mathrm{Cu}$ content is increased for sub-stoichiometric conditions in the air reactor (black lines), a lower air/ $\mathrm{Cu}$ ratio is required in the air reactor and the fuel reactor/calciner is fed with a $\mathrm{CuO} / \mathrm{Cu}_{2} \mathrm{O}$ mixture with an increasing $\mathrm{Cu}_{2} \mathrm{O}$ content. On the right hand side of the chart, the $\mathrm{Cu}$ content is sufficiently high to allow the targeted temperature in the air reactor to be reached with a lower air-to- $\mathrm{Cu}$ ratio, generating the $\mathrm{Cu}_{2} \mathrm{O} / \mathrm{Cu}$ mixture. At the boundary of these two zones, within a limited $\mathrm{Cu}$ content range of $2.4-2.5 \%$, two solutions are possible as a consequence of the discontinuity observed in Figure 4 and the target air reactor temperature can be achieved with both the $\mathrm{Cu}_{2} \mathrm{O} / \mathrm{CuO}$ and the $\mathrm{Cu} / \mathrm{Cu}_{2} \mathrm{O}$ mixtures.

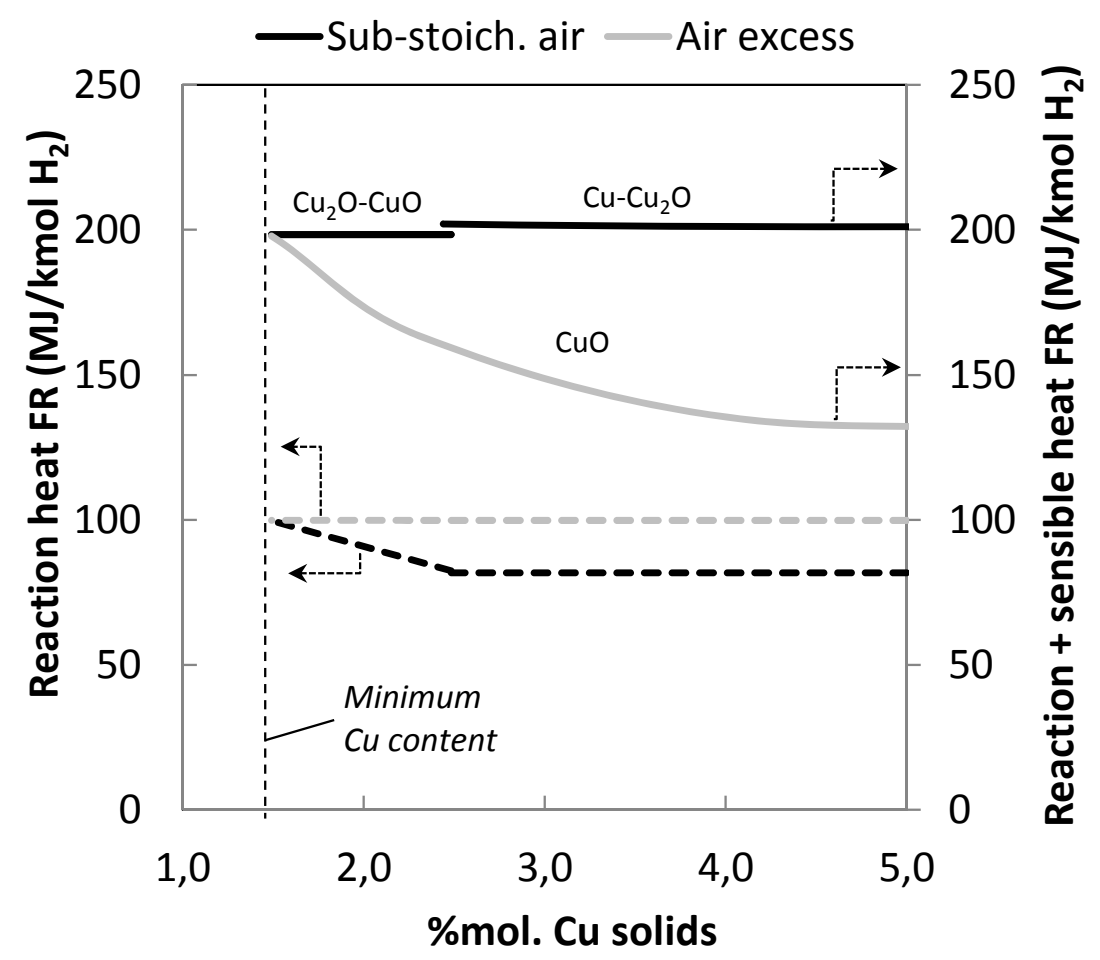

Figure 5. Heat provided in the fuel reactor/calciner (operated at $870^{\circ} \mathrm{C}$ ) per kmole of $\mathrm{H} 2$ consumed in this reactor as a function of the $\mathrm{Cu}$ molar content in the solids from the air reactor (operated at $900^{\circ} \mathrm{C}$ ) operating with sub-stoichiometric (black lines) and over- 
stoichiometric (grey lines) air-to-Cu ratios. The air reactor operates with an air inlet temperature of $300^{\circ} \mathrm{C}$. Hydrogen is assumed to enter the fuel reactor at $870^{\circ} \mathrm{C}$ and to be fully oxidized to $\mathrm{H}_{2} \mathrm{O}$. Copper is assumed to be fully reduced by hydrogen in the fuel reactor/calciner.

The energy provided to the fuel reactor/calciner per kmole of $\mathrm{H}_{2}$ consumed depicted in Figure 5 is representative of the useful heat available for sorbent regeneration from the fuel consumed in the fuel reactor. The sub-stoichiometric air-to- $\mathrm{Cu}$ conditions in the air reactor suggest that the total energy (reaction heat + sensible heat transported by the solids: continuous black line) available is barely affected by the solids composition. This heat (about $200 \mathrm{MJ} / \mathrm{kmole}_{\mathrm{H} 2}$ ) corresponds to the heating value of hydrogen, reduced by the sensible heat associated to air heating in the air reactor from its inlet temperature of $300^{\circ} \mathrm{C}$ to $900^{\circ} \mathrm{C}$. Heat loss as air sensible heat remains constant throughout the entire operation range, except when there is a low $\mathrm{Cu}$ content, where a discontinuity again appears. Here, an additional excess of air is needed to achieve $\mathrm{CuO}$ formation and this hot excess air is responsible for an additional heat loss in the air reactor exhausts resulting in less energy being available from $\mathrm{H}_{2}$ oxidation. In any case, the difference in the energy balance is rather small when the system is operated with the $\mathrm{Cu}_{2} \mathrm{O} / \mathrm{CuO}$ couple rather than with the $\mathrm{Cu} / \mathrm{Cu}_{2} \mathrm{O}$ one. This difference will completely disappear if air is fed to the air reactor at $900^{\circ} \mathrm{C}$, eliminating the sensible heat associated with air heating. However, when over-stoichiometric conditions are employed in the air reactor, and therefore with the $\mathrm{Cu} / \mathrm{CuO}$ couple over the whole range of $\mathrm{Cu}$ content explored, the chemical energy recovered from $\mathrm{CuO}$ reduction remains unaltered at around $100 \mathrm{MJ} / \mathrm{kmol} \mathrm{H}$, which corresponds to the enthalpy of reaction (5) at the temperature of $870^{\circ} \mathrm{C}$. As the $\mathrm{Cu}$ content in the solids increases, a higher amount of energy is released from its complete oxidation into $\mathrm{CuO}$ and the amount of air needed for reaching the temperature of $900^{\circ} \mathrm{C}$ in the air reactor is therefore higher. As a consequence, the sensible heat associated to the air reactor exhaust gas rises with the $\mathrm{Cu}$ content, resulting in a continuous decay in the energy available from $\mathrm{H}_{2}$ oxidation in the fuel reactor/calciner.

In Figure 6, the energy provided to the fuel reactor/calciner per $\mathrm{kg}$ of solids circulating in the CLC system and the solids circulation through the air reactor are represented. It can be seen that the higher the energy provided per $\mathrm{kg}$ of solids, the lower the solids circulation rate needed in the CLC loop to provide a given thermal power for the regeneration of the SEWGS sorbent. The total heat (reaction heat + sensible heat: continuous black line in this figure) provided by one $\mathrm{kg}$ of solids is almost independent of the $\mathrm{Cu}$ content in the solids when the system is operating in the $\mathrm{Cu}-\mathrm{Cu}_{2} \mathrm{O}$ zone. This is because the specific heat of the unreacted $\mathrm{Cu}$ with its support (that behaves as inert in such conditions and therefore transfers energy only through its sensible heat) is similar to the specific heat of $\mathrm{CaO}(0.846 \mathrm{~kJ} / \mathrm{kg}-\mathrm{K}$ vs. $0.855 \mathrm{~kJ} / \mathrm{kg}-\mathrm{K})$, that also behaves as inert. Therefore, the heat carrying capacity is basically unaffected by the $\mathrm{Cu}$ content in this operating area. On the other hand, if the system operates in the $\mathrm{Cu}_{2} \mathrm{O}-\mathrm{CuO}$ zone, the energy carried by one $\mathrm{kg}$ of solids increases because all the Copper reacts in the CLC 
loop. By decreasing the $\mathrm{Cu}$ content in the solids, an increasing amount of $\mathrm{Cu}$ is completely oxidized to $\mathrm{CuO}$ in the air reactor. In this way the chemical energy potential of the oxygen carrier is fully exploited. For the lowest feasible $\mathrm{Cu}$ content in the solids going to the air reactor and assuming sub-stoichiometric air-to- $\mathrm{Cu}$ proportions in this reactor, all the copper is oxidized to $\mathrm{CuO}$ and the energy transported per $\mathrm{kg}$ of solids increases by about $18 \%$ with respect to the conditions where $\mathrm{Cu}_{2} \mathrm{O}$ and $\mathrm{Cu}$ coexist, resulting in an equivalent reduction of the solids circulation between the fuel and air reactors. A minimum solids circulation value of around $75 \mathrm{~kg} / \mathrm{m}^{2} \cdot \mathrm{s}$ (calculated assuming a superficial velocity of the gas at the air reactor outlet of $4 \mathrm{~m} / \mathrm{s}$ ) is found when working under these sub-stoichiometric conditions and at a minimum $\mathrm{Cu}$ content, which is higher than the solids circulation conditions typically found for large-scale CFB reactors. Hence, working with reasonable solids circulation values of CFB boilers of 10$20 \mathrm{~kg} / \mathrm{m}^{2} \cdot \mathrm{s}$ implies working with air excess and full oxygen carrier oxidation to $\mathrm{CuO}$ at the air reactor outlet, which results in an increased heat loss associated to the air reactor exhaust gas as observed in Figure 5.

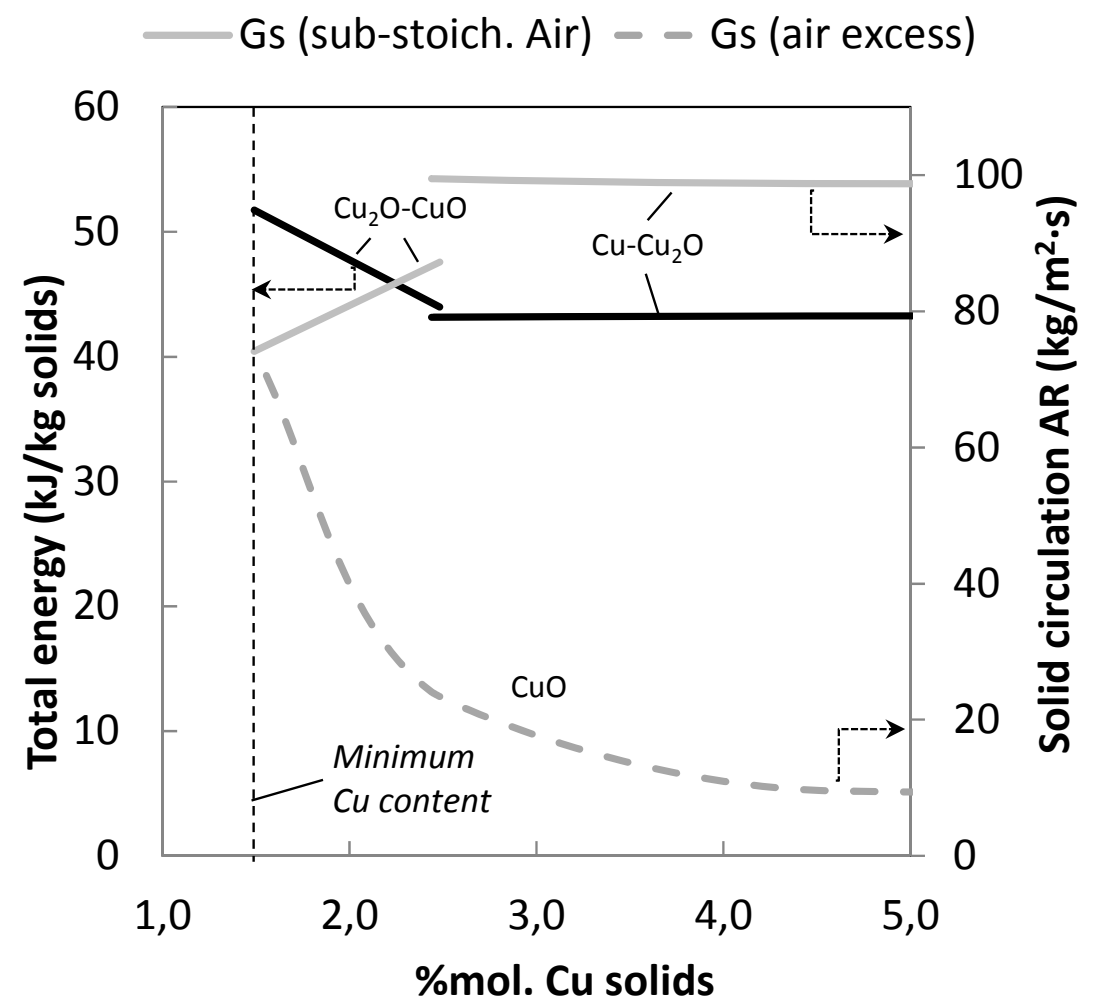

Figure 6. Heat provided to the fuel reactor/calciner (operated at $870^{\circ} \mathrm{C}$ ) per $\mathrm{kg}$ of circulating solids (primary ordinate axis) and solid circulation (secondary ordinate axis) in the air reactor (operated at $900^{\circ} \mathrm{C}$ ) as a function of the $\mathrm{Cu}$ molar content in the solids from the air reactor. Heat to the fuel reactor is calculated with the air reactor operating with fully reduced $\mathrm{Cu}$ at the inlet and with an inlet air temperature of $300^{\circ} \mathrm{C}$. Hydrogen is assumed to enter the fuel reactor at $870^{\circ} \mathrm{C}$ and to be fully oxidized to $\mathrm{H} 2 \mathrm{O}$. Copper is assumed to be fully reduced by hydrogen in the fuel reactor/calciner. Specific solids 
circulation calculated assuming a gas superficial velocity at the air reactor outlet of $4 \mathrm{~m} / \mathrm{s}$.

\subsection{Reference case description}

Based on the analysis above, a reference case has been chosen that assumes that the reducing gas used in the fuel calciner is exclusively the COG from the integrated steel mill. Table 3 indicates the temperature, flow rate and composition of the solid and gas streams obtained by solving the mass and heat balances of the complete $\mathrm{Ca}-\mathrm{Cu}$ looping process, on the basis of the assumptions of Table 2. The heat released from the oxidation of the $\mathrm{COG}$ in the fuel reactor will allow the $\mathrm{CaCO}_{3}$ required in the ironmaking process and the $\mathrm{CaCO}_{3}$ formed by the SEWGS to be calcined. In this case, it is considered that complete oxidation of COG occurs in the fuel reactor/calciner, while oxygen carrier conversion at this reactor outlet has been assumed to be equal to 0.05 (i.e. equivalent to $\mathrm{Cu}_{2} \mathrm{O} / \mathrm{Cu}$ molar ratio of 0.045 at the reactor outlet).

For each tonne of hot roll coil, a mass of $725 \mathrm{~kg}$ of gas (stream 1 in Figure 1) is fed to the SEWGS reactor, resulting from the mixing of $582 \mathrm{~kg}$ of BFG (around 27\% of total $\mathrm{BFG}$ produced per tonne of steel in the steel mill) and $143 \mathrm{~kg}$ of steam used to achieve the target $\mathrm{S} / \mathrm{C}=1$. Performed at $600^{\circ} \mathrm{C}$, the carbonation reaction (Eq. 2) will be sufficiently fast and, as can be seen in Figure 2 and Figure 3, a very high conversion of $\mathrm{CO}$ to $\mathrm{H}_{2}$ (Eq. 1) and a $\mathrm{CO}_{2}$ capture ratio of $99 \%$ is achieved. A mass of around $2529 \mathrm{~kg}$ (stream 5), mainly composed of $\mathrm{CaO}$, arrives at the SEWGS reactor at $870^{\circ} \mathrm{C}$ coming from the fuel reactor calciner. Moreover, it is considered that the make-up stream of 282 $\mathrm{kg}$ of $\mathrm{CaCO}_{3}$ (stream 3 in Figure 1) is fed to the process at the SEGWS reactor inlet at $250^{\circ} \mathrm{C}$ after being preheated using the low temperature heat available in the process, to be heated in this reactor up to $600^{\circ} \mathrm{C}$ and so reduce the heat demand in the fuel reactor/calciner. A mass of $354 \mathrm{~kg}$ of product gas is obtained at $600{ }^{\circ} \mathrm{C}$, containing around 26 vol.\% of $\mathrm{H}_{2}$ and a negligible content of $\mathrm{CO}_{2}$. This decarbonized fuel gas product could be delivered throughout the steel mill to provide heat and/or power, or to boost steel production by the DRI process with nearly zero $\mathrm{CO}_{2}$ emissions, but such a level of detailed integration is beyond the scope of this conceptual study. However, the potential of this last application has been quantified by calculating the maximum amount of iron that could be produced from hematite $\left(\mathrm{Fe}_{2} \mathrm{O}_{3}\right)$, if the $\mathrm{H}_{2}$ produced in the proposed $\mathrm{Ca}-\mathrm{Cu}$ process were fully oxidized. Considering the amount of $\mathrm{H}_{2}$ in stream 2 , a mass of about $183 \mathrm{~kg}$ of reduced iron could be additionally obtained following the DRI route in parallel to the conventional steel mill producing 1 tonne of finished steel. Since both WGS and carbonation reactions are highly exothermic, around $1.8 \mathrm{GJ}$ must be removed from the SEWGS reactor in order to maintain the operation of this stage at $600^{\circ} \mathrm{C}$. As mentioned before, this high quality energy can be efficiently recovered by producing high pressure steam to generate electric power in the power plant. This result clearly indicates the major benefits that the novel process can offer.

From the SEWGS stage, and after its separation from the product gas in a downstream cyclone, a mass of $3182 \mathrm{~kg}$ is obtained (stream 7), containing around $35 \mathrm{wt} . \%$ of 
$\mathrm{CaCO}_{3}$. In order to reduce the energy demand of the calcination stage, a two stage preheating system is proposed to increase the temperature of stream 7 . This heating system can be either based on fluidized bed contactors or on suspension preheaters typically used in cement plants [96]. The high-temperature gas generated in the air reactor can be used in a first heating stage and the $\mathrm{CO}_{2}$-rich gas obtained in the fuel reactor at $870^{\circ} \mathrm{C}$ can be used in the second stage to heat the solids up to temperatures of around $750^{\circ} \mathrm{C}$ avoiding any previous carbonate decomposition. In the first of the preheating stages, the use of a $\mathrm{CO}_{2}$-free gas as a hot source in a temperature range of 600$660^{\circ} \mathrm{C}$ may result in the calcination of a minor fraction of the $\mathrm{CaCO}_{3}$ if particles remain for prolonged times in contact with such gas. In case equilibrium compositions were achieved, it has been estimated that around $3 \%$ of the $\mathrm{CaCO}_{3}$ entering into this preheater would decompose, which would result in a CCR decrease of $0.6 \%$-points. However, due to the low operating temperatures in this preheater that would cause very low kinetics for the calcination reaction, the impact of the $\mathrm{CaCO}_{3}$ decomposition in this first preheater on the global balances would be negligible and could be neglected. Consequently, for the reference case and without considering partial $\mathrm{CaCO}_{3}$ calcination in this first solid preheating section, the sensible heat from these two hot product streams is sufficiently high to heat the solids fed to the fuel reactor up to $721^{\circ} \mathrm{C}$.

Table 3. Temperature, mass and composition of the streams of the $\mathrm{Ca}-\mathrm{Cu}$ looping process represented in Figure 1, assuming the conditions listed in Table 2.

\begin{tabular}{|c|c|c|c|c|c|c|c|c|c|c|}
\hline Stream & 1 & 2 & 5 & 7 & 8 & 9 & 10 & 11 & 12 & 13 \\
\hline $\mathrm{T},{ }^{\circ} \mathrm{C}$ & 250 & 600 & 870 & 600 & 600 & 870 & 870 & 300 & 900 & 900 \\
\hline $\begin{array}{l}\text { Mass, } \\
\mathrm{kg} / \mathrm{t}_{\text {steel }}\end{array}$ & 725 & 354 & 2529 & 3182 & 78 & 801 & 66228 & 997 & 770 & 66456 \\
\hline $\begin{array}{l}\text { Moles, } \\
\text { kmole } / \mathrm{t}_{\text {steel }}\end{array}$ & 27.2 & 18.7 & 44.3 & 47.1 & 8.0 & 24.0 & 1159.2 & 34.7 & 27.7 & 1145.0 \\
\hline \multicolumn{11}{|c|}{ Composition (wt.\%) } \\
\hline $\mathrm{CaCO}_{3}$ & - & - & - & 35.5 & - & - & - & - & - & - \\
\hline $\mathrm{CaO}$ & - & - & 93.8 & 59.6 & - & - & 93.8 & - & - & 93.5 \\
\hline $\mathrm{Cu}$ & - & - & 3.0 & 2.6 & - & - & 3.0 & - & - & 0.3 \\
\hline $\mathrm{CuO}$ & - & - & - & - & - & - & - & - & - & - \\
\hline $\mathrm{Cu}_{2} \mathrm{O}$ & - & - & 0.3 & - & - & - & 0.3 & - & - & 3.4 \\
\hline $\mathrm{Al}_{2} \mathrm{O}_{3}$ & - & - & 2.9 & 2.3 & - & - & 2.9 & - & - & 2.9 \\
\hline \multicolumn{11}{|c|}{ Composition $(\% \mathrm{~mol})$} \\
\hline $\mathrm{H}_{2}$ & 2.6 & 26.3 & - & - & 59.5 & - & - & - & - & - \\
\hline $\mathrm{CO}$ & 15.8 & 0.1 & - & - & 3.8 & - & - & - & - & - \\
\hline $\mathrm{CH}_{4}$ & - & - & - & - & 23.0 & - & - & - & - & - \\
\hline $\mathrm{H}_{2} \mathrm{O}$ & 31.5 & 23.1 & - & - & 4.0 & 39.6 & - & 2.6 & 3.2 & - \\
\hline $\mathrm{CO}_{2}$ & 15.6 & 0.3 & - & - & 1.0 & 58.5 & - & - & - & - \\
\hline $\mathrm{O}_{2}$ & - & - & - & - & 0.2 & - & - & 20.4 & - & - \\
\hline $\mathrm{N}_{2}$ & 34.5 & 50.1 & - & - & 5.8 & 1.9 & - & 76.1 & 95.6 & - \\
\hline
\end{tabular}




\begin{tabular}{|l|c|c|c|c|c|c|c|c|c|c|}
\hline $\mathrm{C}+$ & - & - & - & - & 2.7 & - & - & - & - & - \\
\hline $\mathrm{Ar}$ & - & - & - & - & - & - & - & 0.9 & 1.1 & - \\
\hline
\end{tabular}

In the fuel reactor, solids from the SEWGS reactor (stream 7) are mixed with the solids stream coming from the air reactor, which contains the partially oxidized $\mathrm{Cu}$ material in the form of $\mathrm{Cu} / \mathrm{Cu}_{2} \mathrm{O}$, as explained later on in this section. The heat necessary to heat up solids from the SEWGS reactor up to $870^{\circ} \mathrm{C}$ as well as to carry out the calcination of the $\mathrm{CaCO}_{3}$ contained in this solid stream is supplied by the exothermic reduction of the $\mathrm{Cu}_{2} \mathrm{O}$ with the $\mathrm{COG}$ (stream 8) together with the sensible heat contained in stream 13 that comes from the air reactor at $900^{\circ} \mathrm{C}$. The $\mathrm{COG}$ is assumed to be fed into the fuel reactor at $600^{\circ} \mathrm{C}$. The calcination reaction is limited by the $\mathrm{CaCO}_{3} / \mathrm{CaO} / \mathrm{CO}_{2}$ equilibrium, which is strongly affected by the temperature and the partial pressure of $\mathrm{CO}_{2}$ in the reaction atmosphere [84]. A minimum temperature of $870{ }^{\circ} \mathrm{C}$ $\left(\mathrm{P}_{\mathrm{CO} 2 \mathrm{eq}, 870^{\circ} \mathrm{C}}=0.65\right)$ in the fuel reactor is assumed in order to ensure the complete calcination of the $\mathrm{CaCO}_{3}$ fed into this reaction stage with enough solids residence time in this reactor (i.e., around 3-5 min of solid residence time is needed according to [97] for this calciner temperature, which is $7^{\circ} \mathrm{C}$ above the temperature corresponding to the equilibrium for the $\mathrm{CO}_{2}$ partial pressure of 0.59 bar present at the fuel reactor outlet). As mentioned before, it is considered that at $870{ }^{\circ} \mathrm{C}$, the complete oxidation of the COG to $\mathrm{CO}_{2}$ and $\mathrm{H}_{2} \mathrm{O}$ is reached, while a small fraction of unconverted $\mathrm{Cu}_{2} \mathrm{O}$ remains in the solid at the fuel reactor outlet. A mass of $801 \mathrm{~kg}$ (with a content of $58.5 \%$ of $\mathrm{CO}_{2}$ ) is obtained as gaseous product (stream 9 in Figure 1) at $870{ }^{\circ} \mathrm{C}$, from which $\mathrm{CO}_{2}$ can be easily purified, and made suitable for transport and storage. The amount of $\mathrm{CO}_{2}$ captured corresponds to approximately $31 \%$ of total $\mathrm{CO}_{2}$ emissions from the reference integrated steelworks. The fuel reactor calciner operates as a bubbling bed and it must be designed to allow for a well-mixed section where the simultaneous $\mathrm{CuO}$ reduction and $\mathrm{CaCO}_{3}$ calcination take place. Therefore, no segregation of either $\mathrm{Cu}$ - and $\mathrm{Ca}$-based particles is assumed to occur in this section in the reference case. Therefore, the solids streams directed to the air reactor (stream 10) and to the SEWGS reactor (stream 6) will have the same composition. In a different section (or reactor, not shown here for simplicity), there will be an effective solids segregation in order to obtain a purge of $158 \mathrm{~kg}$ of pure $\mathrm{CaO}$ (stream 4 in Figure 1) for its use in the steel mill, as explained above.

A high proportion of inerts $(\mathrm{CaO})$ circulating between the fuel reactor and the air reactor is proposed to increase the heat transport capacity of the solids leaving the air reactor (stream 13) to the fuel reactor. A chemical loop using iron oxides to carry out the $\mathrm{CaCO}_{3}$ calcination could also arise as a promising alternative, since iron oxides have a very high heat transfer capacity [44]. However, their reduction with the COG in the fuel reactor is almost neutral $\left(\Delta \mathrm{H}_{\text {red,H2 }}=-5.8 \mathrm{~kJ} / \mathrm{mol}\right)$ and the high temperatures achieved in the air reactor (higher than $1000^{\circ} \mathrm{C}$ ) make it necessary to include a very effective segregation stage downstream the fuel reactor-calciner to avoid the feed of Ca-based solids to the air reactor and the subsequent decrease in their sorption capacity after a 
few cycles. For the reference case and as indicated before, a $\mathrm{Cu} / \mathrm{CaO}$ molar ratio of 0.03 is assumed in stream 10 that comes into the air reactor, which means a total $\mathrm{Cu}$ content of $3.2 \mathrm{wt} . \%$ in this solids stream. Under these conditions, the oxidation stage needs to be carried out with an air/ $\mathrm{Cu}$ mass ratio of around 0.46 in order to limit the oxidation temperature at $900{ }^{\circ} \mathrm{C}$, which falls in the $\mathrm{Cu}-\mathrm{Cu}_{2} \mathrm{O}$ region, as shown in Figure 4. In order to supply the air demanded for the $\mathrm{Cu}$ oxidation, a mass of $997 \mathrm{~kg}$ of air preheated at $300{ }^{\circ} \mathrm{C}$ (stream 11) is fed into the air reactor. Under these circumstances, a solid/gas mass ratio of around 66 would be needed in the air reactor, which corresponds to a solids circulation of around $99 \mathrm{~kg} / \mathrm{m}^{2} \cdot \mathrm{s}$ through the air reactor, assuming a gas superficial velocity of $4 \mathrm{~m} / \mathrm{s}$ in this reactor. This solids circulation is significantly higher than the typical circulation rate in conventional CFB boilers and its feasibility should be experimentally verified. After the separation of the solids (stream 13) from the product gas in a downstream cyclone, they are directed to the fuel reactor to complete the chemical loop. A mass of $770 \mathrm{~kg}$ of $\mathrm{O}_{2}$-depleted air (stream 12) is obtained as oxidation product, which is highly suitable for use in preheating stages and/or for heat recovery and power generation.

Energy introduced into the $\mathrm{Ca}-\mathrm{Cu}$ chemical looping process with the $\mathrm{COG}$ and $\mathrm{BFG}$ streams is distributed among sensible and reaction heats as indicated in the Sankey diagram shown in Figure 7. In other words, energy introduced into the process ends up as chemical energy in the $\mathrm{H}_{2}$ output, as high temperature heat inside the SEWGS reactor, as sensible heat in the gas streams from the whole process and as energy for calcining the fresh $\mathrm{CaCO}_{3}$ introduced into the system (available as $\mathrm{CaO}$ for use in the steel plant). As can be seen in Figure 7,69\% of the total thermal input introduced into the process is fed to the fuel reactor with the COG. The remaining $31 \%$ of the total thermal input is BFG introduced into the SEWGS reactor, which represents around $27 \%$ of the total BFG produced in the integrated steelworks, as explained above. If the $\mathrm{H}_{2}$ output from this process was used for the direct reduction of iron ore, the amount of direct iron produced from DRI might represent around $18.3 \%$ of the steel produced in the integrated steelworks. As can be appreciated from Figure 7, a larger fraction of heat (i.e. almost $39.5 \%$ of the total thermal input) is recovered as high temperature heat in the SEWGS reactor, which can be used for producing electricity. A significant energy output $(11.3 \%)$ is used for $\mathrm{CaO}$ production, calculated as the reaction heat of $\mathrm{CaCO}_{3}$ calcination. Chemical energy (LHV-based) from the $\mathrm{H}_{2}$ produced is $26.8 \%$ of the total thermal input introduced with BFG and COG, which measures the Cold Gas Efficiency (CGE) of the system. Finally, as appreciated in this figure, there is a noticeable fraction of sensible heat in the exhaust gases that can be still recovered after heating up incoming fuel gases up to the reactor feeding temperatures shown in Table 2. This residual heat accounts for $22.4 \%$ of total fuel thermal input introduced into the process, and represents a potential heat source for steam production together with the heat recovered inside the SEWGS reactor. These heat sources account for more than $60 \%$ of the thermal power introduced with $\mathrm{COG}$ and $\mathrm{BFG}$ into the $\mathrm{Ca}-\mathrm{Cu}$ process, highlighting the possibility of coupling the proposed process with a steam production system for 
producing power in a steam turbine. Additional information about the performance of this reference case study can be found in Table 4.

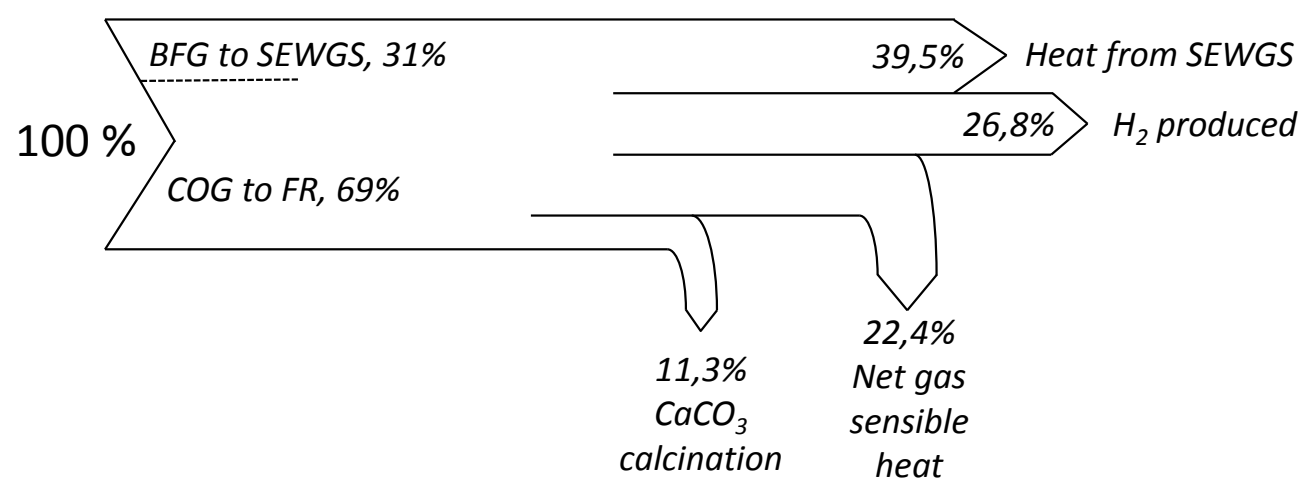

Figure 7. Sankey diagram of the energy balance of the process for the reference case conditions.

\subsection{Sensitivity analysis}

\subsubsection{Effect of operating temperature in the fuel reactor calciner}

One of the objectives of the proposed concept to ensure that $\mathrm{CaCO}_{3}$ calcination occurs thanks to the energy released from reducing $\mathrm{CuO}$ or $\mathrm{Cu}_{2} \mathrm{O}$ present in the solid material almost completely to $\mathrm{Cu}$ (i.e. maintaining the $\mathrm{Cu}_{2} \mathrm{O} / \mathrm{Cu}$ ratio indicated in Table 2), as well as to the sensible heat released by cooling high temperature solids from the air reactor. As mentioned before, the operating temperature of $870^{\circ} \mathrm{C}$ chosen for the fuel reactor calciner of the reference case study was $7^{\circ} \mathrm{C}$ above that corresponding to the $\mathrm{CaO} / \mathrm{CaCO}_{3}$ equilibrium temperature for the $\mathrm{CO}_{2}$ partial pressure in this reactor of 0.59 bar. To facilitate the calcination of $\mathrm{CaCO}_{3}$ in this reactor and to reduce the residence time needed to achieve complete regeneration, a higher margin with respect to the equilibrium may be adopted. For example, a minimum temperature difference with respect to that of equilibrium of around $15-20^{\circ} \mathrm{C}$ is proposed [98]. On the basis of this temperature margin, the effect of increasing the operating temperature in the fuel reactor calciner up to $880^{\circ} \mathrm{C}$ was analyzed. Table 4 summarises the results obtained from this analysis (referred to as Case Tcalc+ in the table). As can be appreciated, the effect of this increased fuel reactor temperature is reflected in the solids circulation between the air reactor and the fuel reactor, which increases by $50 \%$ due to the higher thermal input needed in this latest reactor to fulfill a higher operating temperature and to the lower temperature difference of the heat carrying solids which circulate between the fuel reactor/calciner and the air reactor. The gas/solid mass ratio at the air reactor inlet increases up to a value of 100 in this case, which means a solid flow of $150 \mathrm{~kg} / \mathrm{m}^{2} \cdot \mathrm{s}$ in this reactor (calculated assuming a superficial gas velocity of $4 \mathrm{~m} / \mathrm{s}$ ) which is much higher than the usual operation range of this type of circulating fluidised bed reactor [99]. From an overall plant performance point of view, a negligible effect is observed 
when increasing the operating temperature of the fuel reactor calciner. A global CGE of $26.5 \%$ is obtained, considering the total fuel thermal input into the process. With respect to the $\mathrm{CO}_{2}$ emissions from the whole integrated steel mill [4] (i.e. from the power plant, blast furnace and sinter plant), the proposed $\mathrm{Ca}-\mathrm{Cu}$ chemical looping process under these conditions could capture almost $31 \%$ of $\mathrm{CO}_{2}$.

\subsubsection{Effect of excess air in the air reactor}

The effect of working with excess air in the air reactor was also analyzed (Case Air+ in Table 4). In this case, the conditions of the adiabatic air reactor working at $900^{\circ} \mathrm{C}$ are fulfilled by feeding in an air flow rate higher than that needed for the complete oxidation of $\mathrm{Cu}$ to $\mathrm{CuO}$. In such operating conditions, excess air basically acts as a thermal ballast in this reactor reducing the outlet temperature. As can be appreciated in Table 4, the amount of air fed into the air reactor in this case (i.e. the air/FR fuel molar ratio) is twice that of the reference case, resulting in an air/Cu mass ratio of 2.1. As a consequence of these operating conditions, the solids circulation needed between the fuel reactor and air reactor is reduced noticeably to a value of $19.1 \mathrm{~kg} / \mathrm{m}^{2} \cdot \mathrm{s}$ (Table 4). However, hydrogen production in the SEWGS reactor decreases by $30 \%$ and so does the CGE, which drops to $20.7 \%$. This is due to the fact that, as shown in Figure 6 , the sensible heat in the air reactor exhaust gases increases significantly, causing an increase in the gas sensible heat from 22.4 to $37.2 \%$ of the input heat. This indicates that an increasing fraction of the fuel heating value introduced in the fuel reactor is ultimately used to produce hot air from the air reactor, reducing the heat available for heating the solids. As a consequence, less $\mathrm{CaCO}_{3}$ can be calcined in the fuel reactor/calciner and so less BFG can be converted in the SEWGS, which results in a decrease in the amount of $\mathrm{H}_{2}$ produced.

\subsubsection{Effect of fuel partial oxidation in fuel reactor/calciner}

As already mentioned, the complete reduction of $\mathrm{Cu}_{2} \mathrm{O}-\mathrm{CuO}$ compounds into $\mathrm{Cu}$ in the fuel reactor calciner cannot be achieved by oxidizing completely the fuel used in this reactor. Low amounts of unburnt compounds coming from the incomplete combustion of fuel gas used in the fuel reactor calciner would be present in the exhaust gas if the complete reduction of $\mathrm{Cu}$-based material into $\mathrm{Cu}$ occurs. The effect of the complete reduction of the $\mathrm{Cu}$-based material in the fuel reactor/calciner on the global process performance was analyzed. The amount of unconverted compounds at fuel reactor exhaust is adjusted to achieve a $\mathrm{CO}_{2}$ concentration of $90 \%$ on a dry basis, which is suitable for an efficient $\mathrm{CO}_{2}$ purification unit with high $\mathrm{CO}_{2}$ capture and a high recovery of the incondensable fuel species.

The performance results obtained for these operating conditions with fuel partial oxidation (POX) are shown in Table 4 and are referred to as Case FR-POX. A loss of a fraction of the chemical energy of the $\mathrm{COG}$ used as fuel in the fuel reactor calciner would entail a reduction in the amount of $\mathrm{CaCO}_{3}$ that could be calcined in this reactor and therefore in the BFG that could be fed into the SEWGS reactor. Consequently, the amount of $\mathrm{H}_{2}$ produced in this case would be reduced. According to the results shown in 
Table 4, almost $3 \%$ less of BFG could be processed with respect to the reference case, which would entail a reduction in the CGE to $25 \%$. Moreover, since the system keeps on working in the $\mathrm{Cu}-\mathrm{Cu}_{2} \mathrm{O}$ zone at air reactor outlet, the solids circulation through this reactor would remain at a very high value of $99.6 \mathrm{~kg} / \mathrm{m}^{2} \cdot \mathrm{s}$.

\subsubsection{Effect of increased $\mathrm{Cu} / \mathrm{Ca}$ ratio}

In this case, the effect of working with a higher amount of $\mathrm{Cu}$ material in the circulating solids and with higher content of oxidized $\mathrm{Cu}$ in the fuel reactor/calciner was analyzed. In the reference case, the $\mathrm{Cu}_{2} \mathrm{O}$ content at fuel calciner reactor outlet was limited to 0.045 moles of $\mathrm{Cu}_{2} \mathrm{O}$ per mole of $\mathrm{Cu}$ (see Table 2), which results in a total $\mathrm{Cu}_{2} \mathrm{O}$ content in the solids bed of the fuel reactor/calciner of around $0.3 \% \mathrm{wt}$. Such a low fraction of oxidized oxygen carrier in the bed may require a very large solids inventory to achieve complete fuel oxidation. An increase in the amount of $\mathrm{Cu}_{2} \mathrm{O}$ in the solid bed material of the fuel reactor calciner of around $4 \% \mathrm{wt}$. was considered in this case for ensuring the complete conversion of COG in this reactor. Based on the modelling results reported in [100], it was estimated that such a concentration of oxidized $\mathrm{Cu}$-based oxygen carrier in the fuel reactor should be enough to ensure complete fuel oxidation with a reasonable solids inventory. Moreover, in order to reduce the solids circulation rate between the fuel calciner reactor and air reactor, the molar $\mathrm{Cu} / \mathrm{CaO}$ ratio in the solids was adjusted so that the air reactor operated close to the stoichiometric conditions (i.e. with complete $\mathrm{Cu}$ oxidation and no air excess in the air reactor). The results obtained for this case (referred to as ' $\mathrm{Cu} / \mathrm{Ca}+$ ') are included in Table 4.

As can be seen in Figure 6, working exclusively with $\mathrm{CuO}$ at the air reactor outlet maximizes the amount of oxygen transferred per unit of mass of solids circulating into the fuel reactor/calciner, which allows reducing the solid circulation needed in the system. From the results shown in Table 4 for this case, it can be seen that solids circulation at the air reactor outlet is greatly reduced by about $40 \%$ with respect to the reference case, reaching a value of $61.8 \mathrm{~kg} / \mathrm{m}^{2} \cdot \mathrm{s}$. One of the negative effects of increasing the $\mathrm{Cu} / \mathrm{Ca}$ ratio and the amount of $\mathrm{Cu}_{2} \mathrm{O}$ at the fuel calciner reactor outlet is that a greater amount of $\mathrm{Cu}_{2} \mathrm{O}$ is sent to the SEWGS reactor. In this reactor, $\mathrm{Cu}$-based material acts as a thermal ballast decreasing the heat available from this reactor and oxidizing part of the $\mathrm{H}_{2}$ formed. As a result, $\mathrm{H}_{2}$ production diminishes and so does the CGE. As can be appreciated in Table 4, the CGE in this case is reduced by around 3\%points with respect to that of the reference case, reaching a value as low as $23.6 \%$.

\subsubsection{Effect of increased $\mathrm{Cu} / \mathrm{Ca}$ ratio and solids segregation}

When increasing the amount of $\mathrm{Cu}$ material in the circulating solids, the segregation of solids in the fuel reactor calciner becomes important to prevent oxidized $\mathrm{Cu}$-based material passing into the SEWGS reactor and so maximizing the $\mathrm{H}_{2}$ produced in the system. This analysis considers the possibility of separating the $\mathrm{Cu} / \mathrm{Al}_{2} \mathrm{O}_{3}$ material completely from $\mathrm{CaO}$ in the segregator, so that pure $\mathrm{CaO}$ can be sent to the SEWGS. 
Taking as reference the $\mathrm{Cu} / \mathrm{Ca}+$ case, because of the absence of $\mathrm{Cu}_{2} \mathrm{O}$ or $\mathrm{CuO}$ at the SEWGS reactor inlet, $\mathrm{H}_{2}$ production is noticeably raised by about $14 \%$ in this case with respect to the case $\mathrm{Cu} / \mathrm{Ca}+$, which results in a CGE as high as $27.1 \%$. Moreover, due to the fact that exclusively $\mathrm{CaO}$ is sent to the SEWGS reactor the amount of heat recovered from this reactor is reduced as can be appreciated in Table 4. 
Table 4. Main performance results for the reference case and those obtained from the sensitivity analysis on the operating temperature in the fuel reactor/calciner (case Tcalc + ) and on the air excess (case Air + ), as well as on partial oxidation of fuel in the fuel reactor calciner (case FR-POX) and on solid composition without and with segregation $(\mathrm{Cu} / \mathrm{Ca}+$ and $\mathrm{Cu} / \mathrm{Ca}+$ seg cases respectively)

\begin{tabular}{|c|c|c|c|c|c|c|}
\hline & $\begin{array}{l}\text { Reference } \\
\text { case }\end{array}$ & Tcalc+ & Air + & FR-POX & $\mathrm{Cu} / \mathrm{Ca}+$ & $\mathrm{Cu} / \mathrm{Ca}+\mathbf{s e g r}$ \\
\hline Fuel reactor temperature $\left[{ }^{\circ} \mathrm{C}\right]$ & $870^{\circ} \mathrm{C}$ & $880^{\circ} \mathrm{C}$ & $870^{\circ} \mathrm{C}$ & $870^{\circ} \mathrm{C}$ & $870^{\circ} \mathrm{C}$ & $870^{\circ} \mathrm{C}$ \\
\hline $\mathrm{Cu}$-to- $\mathrm{CaO}$ molar ratio at air reactor inlet & 0.031 & 0.031 & 0.031 & 0.031 & 0.036 & 0.039 \\
\hline $\mathrm{Cu}$-to-CaO molar ratio at SEWGS reactor inlet & 0.031 & 0.031 & 0.031 & 0.031 & 0.036 & 0 \\
\hline $\mathrm{O}_{2}$ content at air reactor outlet $[\% \mathrm{~mol}]$ & 0 & 0 & 11.4 & 0 & 1.8 & 1.8 \\
\hline \multicolumn{7}{|c|}{ Energy Balance } \\
\hline Thermal fuel input into the SEWGS reactor $\left[\mathrm{MW}_{\mathrm{LHV}}\right]$ & 1384 & 1367 & 968 & 1237 & 1424 & 1384 \\
\hline Thermal fuel input into the FR $\left[\mathrm{MW}_{\mathrm{LHV}}\right]$ & 3080 & 3080 & 3080 & 3080 & 3080 & 3080 \\
\hline Heating value of $\mathrm{H}_{2}$ produced [\% of total fuel input] & 26.8 & 26.5 & 20.7 & 25.0 & 23.6 & 27.1 \\
\hline Heat available from SEWGS reactor [\% of total fuel input] & 39.5 & 39.6 & 29.7 & 36.2 & 41.7 & 38.7 \\
\hline Sensible heat of gases [\% of total fuel input] & 22.4 & 22.5 & 37.2 & 21.4 & 23.5 & 23.0 \\
\hline $\begin{array}{l}\text { Heat needed for calcining } \mathrm{CaCO}_{3} \text { make-up in the } \mathrm{FR}[\% \text { of total fuel } \\
\text { input] }\end{array}$ & 11.3 & 11.7 & 12.4 & 11.7 & 11.2 & 11.3 \\
\hline Residual heating value of FR exhaust [\% of total fuel input] & -- & -- & -- & 5.8 & -- & -- \\
\hline \multicolumn{7}{|c|}{ General stream information } \\
\hline Solid/gas mass ratio at AR inlet & 66.4 & 100.1 & 14.3 & 66.3 & 41.8 & 40.9 \\
\hline $\mathrm{G}_{\mathrm{s}}$ at air reactor outlet ${ }^{*}\left[\mathrm{~kg} / \mathrm{s} / \mathrm{m}^{2}\right]$ & 99.8 & 150.2 & 19.1 & 99.6 & 61.8 & 60.4 \\
\hline Air/FR fuel molar ratio & 4.3 & 4.3 & 8.8 & 4.1 & 4.9 & 4.7 \\
\hline Solids/FR fuel mass ratio & 892.8 & 1322.2 & 400.9 & 830.7 & 650.3 & 604.5 \\
\hline $\mathrm{Cu} / \mathrm{Cu}_{2} \mathrm{O} / \mathrm{CuO}$ content in solids from $\mathrm{AR}[\% \mathrm{~mol}]$ & $0.25 / 1.36 /-$ & $1.07 / 0.94 /-$ & $-/-/ 2.90$ & $0.44 / 1.24 /-$ & $-/-/ 3.41$ & $-/-/ 3.68$ \\
\hline $\mathrm{Cu} / \mathrm{Cu}_{2} \mathrm{O} / \mathrm{CuO}$ content in solids from fuel reactor calciner to $\mathrm{AR}$ [\%mol] & $2.69 / 0.12 /-$ & $2.69 / 0.12 /-$ & $2.69 / 0.12 /-$ & 2.89/-/- & $0.21 / 1.64 /-$ & $0.03 / 1.87 /-$ \\
\hline Fraction of total BFG sent to SEWGS [\%] & 26.8 & 26.4 & 18.7 & 23.9 & 27.6 & 26.8 \\
\hline \multicolumn{7}{|c|}{ General performance parameters } \\
\hline Hydrogen output at SEWGS outlet [MW $\mathrm{MHV}_{\mathrm{LHV}}$ & 1195 & 1180 & 836 & 1080 & 1065 & 1209 \\
\hline $\mathrm{H}_{2}$ production $\left[\mathrm{m}^{3} \mathrm{~N} / \mathrm{t}\right.$ steel $]$ & 110 & 109 & 77 & 99 & 98 & 111 \\
\hline $\mathrm{CO}_{2}$ captured $\left[\mathrm{kg} \mathrm{CO}_{2}\right.$ at calciner outlet/ $\mathrm{t}$ steel $]$ & 617 & 612 & 505 & 552 & 628 & 617 \\
\hline
\end{tabular}




\begin{tabular}{|l|l|l|l|c|c|c|}
\hline $\mathrm{CO}_{2}$ capture ratio [\% with respect to total $\mathrm{CO}_{2}$ emissions in steel mill] & 31.2 & 31.0 & 25.6 & 27.9 & 31.8 & 31.2 \\
\hline $\begin{array}{l}\text { Additional amount of Fe produced by direct reduction of } \mathrm{Fe}_{2} \mathrm{O}_{3} \text { with } \mathrm{H}_{2} \\
\text { produced [ton/ton steel] }\end{array}$ & 0.183 & 0.181 & 0.128 & 0.165 & 0.163 & 0.185 \\
\hline
\end{tabular}

evaluated assuming a gas superficial velocity of $4 \mathrm{~m} / \mathrm{s}$ at air reactor outlet 


\section{Conclusions}

A comprehensive conceptual design of a novel $\mathrm{Ca}-\mathrm{Cu}$ looping process for producing a $\mathrm{H}_{2}$-enriched fuel gas via the sorption enhanced water gas shift (SEWGS) of blast furnace gas (BFG) using $\mathrm{CaO}$ as $\mathrm{CO}_{2}$ sorbent has been carried out. Operating windows for the different reactions steps required in the process have been found to be consistent with the state of the art of the gas-solid reactions required in the process. On the basis of a reference case operated at reasonable conditions (i.e., the SEWGS stage performed at $600^{\circ} \mathrm{C}$, regeneration of the Ca-based sorbent carried out at $870^{\circ} \mathrm{C}$ using as fuel gas exclusively COG from the steel mill, and the oxidation stage carried out under substoichiometric conditions to limit the reactor temperature up to $900^{\circ} \mathrm{C}$ ), it is estimated that around $27 \%$ of the BFG can be decarbonized in the SEWGS reactor, producing 110 $\mathrm{Nm}^{3}$ of $\mathrm{H}_{2}$ per tonne of steel and reaching a $\mathrm{CO}_{2}$ capture ratio of $31 \%$ with respect to the total carbon emissions in the steel mill. The SEWGS stage carried out at $600^{\circ} \mathrm{C}$ with a $\mathrm{S} / \mathrm{C}$ molar ratio of 1 allows high $\mathrm{H}_{2}$ yield in the product gas (up to $96 \mathrm{vol.} \% \mathrm{H}_{2}, \mathrm{~N}_{2}$ free and on a dry basis) and high $\mathrm{CO}_{2}$ capture efficiency (around 95\%) to be achieved with moderate steam consumption and reasonably fast reaction rates. The air-to- $\mathrm{Cu}$ ratio and the inerts content in the oxidation stage strongly affect the proportion of $\mathrm{Cu} / \mathrm{Cu}_{2} \mathrm{O} / \mathrm{CuO}$ formed during the oxidation as well as the maximum temperature achieved in the air reactor. The targeted temperature in the air reactor of $900^{\circ} \mathrm{C}$ can be achieved either by performing under sub-stoichiometric or under over-stoichiometric conditions. At lower air-to- $\mathrm{Cu}$ ratios, the $\mathrm{Cu}$ is not completely oxidized to $\mathrm{CuO}$, and therefore, the chemical energy potential of the oxygen carrier between the air reactor and the fuel reactor is not fully exploited. However, the heat loss associated to the exhaust gas of the air reactor decreases, since a lower flow of air is needed, resulting in an increase in the energy available from the COG oxidation in the fuel reactor/calciner. This means that higher amounts of $\mathrm{CaCO}_{3}$ can be calcined, which allows a higher $\mathrm{H}_{2}$ production in the SEWGS stage to be achieved. Nevertheless, the $\mathrm{Cu}$ oxidation under sub-stoichiometric conditions requires higher solids circulation rates in the CLC loop (around $100 \mathrm{~kg} / \mathrm{m}^{2} \mathrm{~s}$ ) to provide a given thermal power for the $\mathrm{CaCO}_{3}$ calcination, which are far above the typical rates for CFB boilers (between 10 and $30 \mathrm{~kg} / \mathrm{m}^{2} \mathrm{~s}$ ). The analysis also shows that the increase in the $\mathrm{Cu} / \mathrm{Ca}$ ratio in the circulating solids and assuming an effective segregation of the $\mathrm{Ca}$ - and $\mathrm{Cu}$-based solids in the fuel reactor-calciner allow high $\mathrm{H}_{2}$ production and high $\mathrm{CO}_{2}$ capture ratios to be achieved with significantly lower solids circulation rates between the air reactor and the fuel reactor (around $60 \mathrm{~kg} / \mathrm{m}^{2} \mathrm{~s}$ ). A Sankey diagram shows that around $27 \%$ of the energy introduced into the process ends as chemical energy in the $\mathrm{H}_{2}$ output, while more than $60 \%$ of the thermal input ends as high temperature heat generated in the SEWGS reactor and as sensible heat in the exhaust gases that can be efficiently recovered in a steam cycle to generate electric power. These results confirm the potential of this novel $\mathrm{Ca} / \mathrm{Cu}$ looping process as a precombustion $\mathrm{CO}_{2}$ capture technology for $\mathrm{H}_{2}$ production and power generation in steel mills. 


\section{Acknowledgements}

The authors acknowledge the financial support from the ASCENT (Advanced solid cycles with efficient novel technologies) Project funded by the European Union Seventh Framework Programme FP7 under Grant agreement no.608512.

\section{References}

[1] IPCC, 2014- Climate Change 2014: Mitigation of Climate Change. Contribution of Working Group III to the Fifth Assessment Report of the Intergovernmental Panel on Climate Change [Edenhofer, O., R. Pichs-Madruga, Y. Sokona, E. Farahani, S. Kadner, K. Seyboth, A. Adler, I. Baum, S. Brunner, P. Eickemeier, B. Kriemann, J. Savolainen, S. Schlömer, C. von Stechow, T. Zwickel and J.C. Minx (eds.)]. Cambridge University Press, Cambridge, United Kingdom and New York, NY, USA.

[2] M.T. Ho, A. Bustamante, D.E. Wiley, Comparison of $\mathrm{CO}_{2}$ capture economics for iron and steel mills, International Journal of Greenhouse Gas Control, 19 (2013) 145159.

[3] ZEP, CCS for Industry: Modelling the lowest-cost route to decarbonizing Europe, 2015

[4] S. Santos, Overview of the current state and development of $\mathrm{CO}_{2}$ capture technologies in the ironmaking process, IEA Publications, Cheltenham, UK, 2013.

[5] Birat, J. Steel and $\mathrm{CO}_{2}$-the ULCOS Program, CCS and Mineral Carbonation using Steelmaking Slag. Arcelor Mittal-Maizieres-les-Metz, 2008.

[6] Tonomura, S. Outline of Course 50. Energy Procedia, 37 ( 2013 ) 7160-7167.

[7] Kuramochi, T., Ramirez, A., Turkenburg, W., Faaij, A, Comparative assessment of $\mathrm{CO}_{2}$ capture technologies for carbon-intensive industrial processes, Progress in Energy and Combustion Science, 38 (2012) 87-112.

[8] Cheng, H.H., Shen, J.F., Tan, C.S., $\mathrm{CO}_{2}$ capture from hot stove gas in steel making process, International Journal of Greenhouse Gas Control, 4 (2010) 525-531.

[9] Arasto, A., Tsupari, E., Kärki, J., Pisilä, E., Sorsamäki, L. Post-combustion capture of $\mathrm{CO}_{2}$ at an integrated steel mill-Part I: Technical concept analysis, International Journal of Greenhouse Gas Control, 16 (2013) 271-277.

[10] Gazzani, M., Romano, M.C., Manzolini, G. $\mathrm{CO}_{2}$ capture in integrated steelworks by comercial-ready technologies and SEWGS process, International Journal of Greenhouse Gas Control, 41 (2015) 249-267.

[11] Romano, M.C., Anantharaman, R., Arasto, A., Ozcan, D.C., Ahn, H., Dijkstra, J.W., Carbo, M., Boavida, D., Application of advanced technologies for $\mathrm{CO}_{2}$ capture from industrial sources, Energy Procedia, 37 (2013) 7176-7185. 
[12] Allam, R.J., Chiang, R., Hufton, J.R., Middleton, P., Weist, E.L., White, V. Development of the Sorption Enhanced Water Gas Shift Process, Carbon Dioxide Capture for Storage in Deep Geologic Formations, 227-256, Elsevier, Amsterdam, 2005.

[13] Liu, Y., Li, Z., Cai, N., 2012. Effect of Sorbent Type on the Sorption Enhanced Water Gas Shift Process in a Fluidized Bed Reactor. Ind. Eng. Chem. Res. 51, 11989-11997.

[14] STEPWISE European H2020 Project (http://www.stepwise.eu/).

[15] Wright, A.D., White, V., Hufton, J.R., Quinn, R., Cobden, P.D., van Selow, E.R., CAESAR: Development of a SEWGS model for IGCC, Energy Procedia 4 (2011) $1147-1154$.

[16] E. R. van Selow, P. D. Cobden, P. A. Verbraeken, J. R. Hufton, R. W. van den Brink, 2009. Carbon Capture by Sorption-Enhanced Water-Gas Shift Reaction Process using Hydrotalcite-Based Material. Ind. Eng. Chem. Res. 48, 4184-4193.

[17] Jansen, D., van Selow, E., Cobden, P., Manzolini, G., Macchi, E., Gazzani, M., Blom, R., Henriksen, P., Beavis, R., Wright, A, SEWGS technology is now ready for scale-up! Energy Procedia 37 ( 2013) 2265-2273.

[18] Boon, J., Cobden, P.D., van Dijk, H.a.J., van Sint Annaland, M., 2015, Hightemperature pressure swing adsorption cycle design for sorption-enhanced water-gas shift. Chem. Eng. Sci. 122, 219-231.

[19] Blamey, J., Anthony, E.J., Wang, J, Fennell, P.S., 2010. The calcium looping cycle for large-scale $\mathrm{CO}_{2}$ capture. Progress in Energy and Combustion Science 36, 260-279-

[20] Kierzkowska, A. M., Pacciani, R., Müller, C. R., 2013. CaO-Based $\mathrm{CO}_{2}$ Sorbents: From Fundamentals to the Development of New, Highly Effective Materials. Chem. Sus. Chem. 6 (7) 1130-1148.

[21] Erans, M., Manovic, V., Anthony, E.J., 2016. Calcium looping sorbents for $\mathrm{CO}_{2}$ capture. Applied Energy 180, 722-742.

[22] Balasubramanian, B., Lopez Ortiz, A., Kaytakoglu, S., Harrison, D.P., 1999. Hydrogen from methane in a single-step process. Chem. Eng. Sci. 54, 3543-3552.

[23] Harrison, D.P., 2008. Sorption-enhanced hydrogen production: a review. Ind. Eng. Chem. Res. 47, 6486-6501.

[24] Wu, Y.J., Li, P., Yu, J.G., Cunha, A.F., Rodrigues, A.E., 2016. Progress on sorption-enhanced reaction process for hydrogen production. Reviews in Chemical Engineering, 32 (3) 271-303. 
[25] Müller, C. R.; Pacciani, R.; Bohn, C. D.; Scott, S. A.; Dennis, J.S. 2009. Investigation of the enhanced water gas shift reaction using natural and synthetic sorbents for the capture of $\mathrm{CO}_{2}$. Ind. Eng. Chem. Res. 48, 10284-10291.

[26] Ramkumar, S., Fan, L.S., Calcium Looping Process (CLP) for Enhanced Non catalytic Hydrogen Production with Integrated Carbon Dioxide Capture, Energy Fuels 2010, 24, 4408-4418.

[27] Weimer T, Berger R, Hawthorne C, Abanades JC. Lime enhanced gasification of solid fuels: Examination of a process for simultaneous hydrogen production and $\mathrm{CO}_{2}$ capture. Fuel 2008; 87(8-9):1678-86.

[28] Chen Z, Grace JR, Lim CJ. $\mathrm{CO}_{2}$ capture and hydrogen production in an integrated fluidized bed reformer regenerator system. Ind Eng Chem Res 2011; 50:4716-4721.

[29] Martínez, I., Romano, M.C., Chiesa, P., Grasa, G., Murillo, R., 2013. Hydrogen production through sorption enhanced steam reforming of natural gas: thermodynamic plant assessment. Int. J. Hydrog. Energy 38, 15180-15199.

[30] Rodríguez, N., Murillo, R., Abanades, J. C. 2012. $\mathrm{CO}_{2}$ Capture from Cement Plants Using Oxyfired Precalcination and/ or Calcium Looping. Environmental Science \& Technology 46, 2460-2466.

[31] Abanades, J.C., Anthony, E.J., Wang, J., Oakey, J.E., 2005. Fluidized bed combustion systems integrating $\mathrm{CO}_{2}$ capture with $\mathrm{CaO}$. Environ. Sci. Technol. 39, 2861-2866.

[32] Grasa, G., Abanades, J. C., 2007. Narrow fluidised beds arranged to exchange heat between a combustion chamber and a $\mathrm{CO}_{2}$ sorbent regenerator. Chemical Engineering Science 62, 619-626.

[33] Junk, M., Reitz, M., Strohle, J., Epple, B., 2013. Thermodynamic evaluation and cold flow model testing of an indirectly heated carbonate looping process. Chem. Eng. Technol. 36, 1479-1487.

[34] Meyer, J., Mastin, J., Bjørnebøle, T.K., Ryberg, T., Eldrup,N., 2011. Technoeconomical study of the zero emission gas power concept. Energy Procedia 4, 19491956.

[35] Rodríguez, N., Alonso, M., Grasa, G., Abanades, J.C., 2008. Process for capturing $\mathrm{CO}_{2}$ arising from the calcination of the $\mathrm{CaCO} 3$ used in cement manufacture. Environ. Sci. Technol. 42, 6980-6984.

[36] Rodríguez, N., Murillo, R., Alonso, M., Martínez, I., Grasa, G., Abanades, J.C., 2011. Analysis of a process for capturing the $\mathrm{CO}_{2}$ resulting from the precalcination of limestone in a cement plant. Ind. Eng. Chem. Res. 50, 2126-2132. 
[37] Martinez, I., Murillo, R., Grasa, G., Rodriguez, N., Abanades, J.C., 2011. Conceptual design of a three fluidised beds combustion system capturing $\mathrm{CO}_{2}$ with $\mathrm{CaO}$. International Journal of Greenhouse Gas Control, 5, 498-504.

[38] Ishida, M., Jin, H., 1994. A new advanced power-generation system using chemical looping combustion. Energy 19, 415-422.

[39] Lyngfelt A, Leckner B, Mattisson T. A fluidized-bed combustion process with inherent $\mathrm{CO}_{2}$ separation; application of chemical-looping combustion. Chem Eng Sci 2001; 56, 3101-3113.

[40] Adanez, J., Abad, A., Garcia-Labiano, F., Gayan, P., de Diego, L.F., 2012. Progress in chemical-looping combustion and reforming technologies. Prog. Energy Combust. Sci. 38, 215-282.

[41] Kumar RV, Lyon RK, Cole JA. Unmixed reforming: a novel autothermal cyclic steam reforming process. In: Gregoire Padro CEaL, F., editor. Adv Hydrogen Energy. New York, Boston, Dordrecht, London, Moscow: Kluwer Academic Publishers; 2002: p. 31-46.

[42] Dupont, V., Ross, A.B., Knight, E., Hanley, I., Twigg, M.V., Production of hydrogen by unmixed steam reforming of methane, Chemical Engineering Science 63 (2008) 2966-2979.

[43] Wolf, J., Yan, J., 2005. Parametric study of chemical looping combustion for trigeneration of hydrogen, heat, and electrical power with $\mathrm{CO}_{2}$ capture. Int. J. Energy Res. 29, 739-753.

[44] Fernández, J.R., Abanades J.C. 2016. $\mathrm{CO}_{2}$ capture from the calcination of $\mathrm{CaCO}_{3}$ using iron oxide as heat carrier. Journal of Cleaner Production. 112, 1211-1217.

[45] Abanades, J. C., Murillo, R., Fernandez, J.R.; Grasa, G., Martinez, I., 2010. New $\mathrm{CO}_{2}$ capture Process for Hydrogen production Combining $\mathrm{Ca}$ and $\mathrm{Cu}$ Chemical Loops. Environ. Sci. Technol. 44, 6901-6904.

[46] Chuang, S. Y., Dennis, J. S., Hayhurst, A. N., Scott, S. A., 2008. Development and performance of $\mathrm{Cu}$-based oxygen carriers for chemical-looping combustion. Combust. Flame. 154, 109-121.

[47] Manovic, V., Wu, Y., He, I., Anthony, E.J., 2011. Core-in-shell CaO/CuO-based composite for CO2 capture. Ind. Eng. Chem. Res. 50, 12384-12391.

[48] Manovic, V., Anthony, E.J., 2011. Integration of calcium and chemical looping combustion using composite $\mathrm{CaO} / \mathrm{CuO}$-based materials. Environ. Sci. Technol.45, 10750-10756. 
[49] Qin, C., Yin, J., Liu, W., An, H., Feng, B., 2012. Behavior of $\mathrm{CaO} / \mathrm{CuO}$ based composite in a combined calcium and copper chemical looping process. Ind. Eng. Chem.Res. 51, 12274-12281.

[50] Qin, C., Yin, J., Luo, C., An, H., Liu, W., Feng, B., 2013. Enhancing the performance ofCaO/CuO based composite for $\mathrm{CO}$ 2capture in a combined $\mathrm{Ca}-\mathrm{Cu}$ chemicallooping process. Chem. Eng. J. 228, 75-86.

[51] Kierzkowska, A.M., Müller, C.R., 2012. Development of calcium-based,copperfunctionalised $\mathrm{CO} 2$ sorbents to integrate chemical looping combustioninto calcium looping. Energy Environ. Sci. 5, 6061-6065.

[52] Imtiaz, Q., Kierzkowska, A. M., Broda, M., Müller, C. R., 2012. Synthesis of CuRich, $\mathrm{Al}_{2} \mathrm{O}_{3}$-Stabilized Oxygen Carriers Using a Coprecipitation Technique: Redox and Carbon Formation Characteristics. Environ. Sci. Technol. 2012, 46, 3561-3566.

[53] Kierzkowska, A.M., Müller, C.R., 2013. Sol-gel derived, calcium-based,copperfunctionalised $\mathrm{CO} 2$ sorbents for an integrated chemical loopingcombustion-calcium looping CO2capture process. ChemPlusChem 78,92-100.

[54] Fernández, J.R., Abanades, J.C., Murillo, R., Grasa, G., 2012. Conceptual design of a hydrogen production process from natural gas with $\mathrm{CO}_{2}$ capture using a $\mathrm{Ca}-\mathrm{Cu}$ chemical loop. Int. J. Greenh. Gas Control 6, 126-141.

[55] Fernández, J.R., Abanades, J.C., Grasa, G., 2012. Modeling of sorption enhanced steam methane reforming - Part II: simulation within a novel $\mathrm{Ca} / \mathrm{Cu}$ chemical loop process for hydrogen production. Chem. Eng. Sci. 84,12-20.

[56] Fernández, J.R., Abanades, J.C., Murillo, R., 2013. Modeling of Cu oxidation in adiabatic fixed-bed reactor with $\mathrm{N}_{2}$ recycling in a $\mathrm{Ca} / \mathrm{Cu}$ chemical loop. Chem. Eng. J. $232,442-452$.

[57] Martínez, I., Murillo, R., Grasa, G., Fernández, J.R., Abanades, J.C., 2013. Integrated combined cycle from natural gas with $\mathrm{CO}_{2}$ capture using a $\mathrm{Ca}-\mathrm{Cu}$ chemical loop. AIChE J. 59, 2780-2794.

[58] Martínez, I., Romano, M.C., Fernández, J.R., Chiesa, P., Murillo,R., Abanades, J.C., 2014. Process design of a hydrogen production plant from natural gas with $\mathrm{CO}_{2}$ capture based on a novel $\mathrm{Ca} / \mathrm{Cu}$ chemical loop. Appl. Energy 114,192-208.

[59] Qin, C., Feng, B., Yin, J., Ran, J., Zhang, L., Manovic, V. 2015. Matching of kinetics of $\mathrm{CaCO}_{3}$ decomposition and $\mathrm{CuO}$ reduction with $\mathrm{CH}_{4}$ in $\mathrm{Ca}-\mathrm{Cu}$ chemical looping, Chem. Eng. Sci. 262, 665-675.

[60] Ridha, F.N., Lu, D., Macchi, A., Hughes, R.W. 2015. Combined calcium looping and chemical looping combustion cycles with $\mathrm{CaO}-\mathrm{CuO}$ pellets in a fixed bed reactor. Fuel 153, 202-209. 
[61] Alarcón , J. M.; Fernández, J. R. 2015. $\mathrm{CaCO}_{3}$ calcination by the simultaneous reduction of $\mathrm{CuO}$ in a $\mathrm{Ca} / \mathrm{Cu}$ chemical looping process. Chem. Eng. Sci., 137, 254-267.

[62] Martini, M., Gallucci, F., Martinez, I., Romano, M.C., Chiesa, P. Sint Annaland, van, M. Process integration of packed-bed $\mathrm{Ca}-\mathrm{Cu}$ process for high efficiency and nearzero emission hydrogen generation. $6^{\text {th }}$ High Temperature Solid Looping Cycles Network Meeting, 1-2 September 2015, Milan, Italy.

[63] Fernández, J. R.; Alarcón , J. M.; Abanades, J. C. 2016. Investigation of a FixedBed Reactor for the Calcination of $\mathrm{CaCO}_{3}$ by the Simultaneous Reduction of $\mathrm{CuO}$ with a Fuel Gas. Ind. Eng. Chem. Res. 55, 5128-5132.

[64] Martini, M, van den Berg, A, Gallucci, F, van Sint Annaland, M. 2016. Investigation of the process operability windows for $\mathrm{Ca}-\mathrm{Cu}$ looping for hydrogen production with $\mathrm{CO}_{2}$ capture. Chemical Engineering Journal 303, 73-88.

[65] Noorman S, van Sint Annaland M, Kuipers H. 2007, Packed bed reactor technology for chemical-looping combustion. Ind Eng Chem Res 46, 4212-20.

[66] Noorman S, F. Gallucci, M. van Sint Annaland, J.A.M. Kuipers, 2010. Experimental investigation of a $\mathrm{CuO} / \mathrm{Al}_{2} \mathrm{O}_{3}$ oxygen carrier for chemical-looping combustion, Ind. Eng. Chem. Res. 49 (2010) 9720-9728.

[67] Hamers, H.P., Gallucci, F., Cobden, P.D., Kimball, E. van Sint Annaland, M. 2014. CLC in packed beds using syngas and $\mathrm{CuO} / \mathrm{Al}_{2} \mathrm{O}_{3}$ : a model description and experimental validation. Applied Energy, 119, 163-172.

[68] Kooiman, R. F., Hamers, H.P., F. Gallucci, M. van Sint Annaland, 2015. Experimental demonstration of two-stage packed bed chemical-looping combustion using syngas with $\mathrm{CuO} / \mathrm{A} 12 \mathrm{O} 3$ and $\mathrm{NiO} / \mathrm{CaAl} 2 \mathrm{O} 4$ as oxygen carriers, Ind. Eng. Chem. Res. 54, 2001-2011.

[69] Han, L., Bollas, G. M., 2016. Dynamic optimization of fixed bed chemical-looping combustion processes. Energy, 112, 1107-1119.

[70] Brandvoll, O., Bolland, O., 2004. Inherent $\mathrm{CO}_{2}$ capture using chemical looping combustion in a natural gas fired power cycle, J. Eng. Gas Turbines Power, 126, 316321.

[71] Spallina, V., F. Gallucci, M.C. Romano, P. Chiesa, G. Lozza, M. van Sint Annaland, 2013. Investigation of heat management for CLC of syngas in packed bed reactors, Chem. Eng. J. 225, 174-191.

[72] Spallina, V., Gallucci, F., Romano, M.C., van Sint Annaland, M. (2016). Precombustion packed bed chemical looping (PCCL) technology for efficient $\mathrm{H}_{2}$-rich gas production processes. Chemical Engineering Journal, 294, 478-494. 
[73] Spallina, V., Chiesa, P., Martelli, E, Gallucci, F., Romano, M.C., Lozza, G. van Sint Annaland, M. (2015). Reactor design and operation strategies for a large-scale packed-bed CLC power plant with coal syngas. International Journal of Greenhouse Gas Control, 36, 34-50.

[74] Ozcan, D.C., Macchi, A., Lu, D. Y., Kierzkowska, A. M., Ahn, H., Müller, C. R., Brandani, S., 2015. Ca-Cu looping process for $\mathrm{CO}_{2}$ capture from a power plant and its comparison with $\mathrm{Ca}$-looping, oxy-combustion and amine-based $\mathrm{CO}_{2}$ capture processes. Int. J. Greenh. Gas Con. 43, 198-212.

[75] Johnsen K, Ryu HJ, Grace JR, Lim CJ. 2006. Sorption-enhanced steam reforming of methane in a fluidised bed reactor with dolomite as -acceptor. Chem Eng Sci. 61(4): 1195-202.

[76] Meyer, J., Mastin, J., Sanz C. 2014. Sustainable Hydrogen Production from Biogas Using Sorption-Enhanced Reforming. Energy Procedia 63, 6800-6814.

[77] Diem, R., Mueller, S., Fuchs, M., Schmid, J.C., Hofbauer, H., 2015. Sorptionenhanced reforming with limestone from iron production. Biomass Conv. Bioref. 5, 95102.

[78] R. T. Symonds, D. Y. Lu, V. Manovic, E. J. Anthony, 2012. Pilot-scale study of $\mathrm{CO}_{2}$ capture by $\mathrm{CaO}$-based sorbents in the presence of steam and $\mathrm{SO}_{2}$. Ind. Eng. Chem. Res., 51, 7177.

[79] Arias, B. Diego, M.E. Abanades, J.C. Lorenzo, M. Diaz, L. Martínez, D. Alvarez, J. Sánchez-Biezma, A. 2013. Demonstration of steady state $\mathrm{CO}_{2}$ capture in a $1.7 \mathrm{MWth}$ calcium looping pilot. Int. J. Greenh. Gas Con. 18, 237-245.

[80] Dieter, H. Bidwe, A.R., Varela-Duelli, G.,Charitos, A., Hawthorne, C., Scheffknecht, G. 2014. Development of the calcium looping $\mathrm{CO}_{2}$ capture technology from lab to pilot scale at IFK, University of Stuttgart. Fuel, 127, 23-37.

[81] Ströhle, J., Junk, M., Kremer, J., Galloy, A., Epple, B. 2014. Carbonate looping experiments in a $1 \mathrm{MWth}$ pilot plant and model validation. Fuel 127, 13-22.

[82] Chang, M.H., Chen, W.C., Huang, C.M., Liu, W.H., Chou, Y.C., Chang, W.C., Chen, W., Cheng, J.Y., Huang, K.E., Hsu, H.W. 2014. Design and Experimental Testing of a 1.9 MWth Calcium Looping Pilot Plant. Energy Procedia, 63, 2100-2108.

[83] Remus, R., Aguado Monsonet, M.A., Roudier, S., Delgado Sancho, L. Best Available Techniques (BAT) Reference for Iron and Steel production. JRC Report by the EU Comission. 2013.

[84] Baker, E.H., 1962. The calcium oxide-calcium dioxide system in the pressure range 1-300 atmospheres. J. Chem. Soc. 70, 464-470. 
[85] Naimer, N.S., Chiba, T., Nienow, A.W., 1982. Parameter estimation for a solids mixing/ segregation model for gas fluidized beds. Chem. Eng. Sci. 37, 1047-1057.

[86] Smith, R.J.B., Loganathan, M., Shantha, M.S., A Review of the Water Gas Shift Reaction Kinetics, International Journal of Chemical Reactor Engineering, volume 8, Berkeley Electronic Press, Berkeley, CA, 2010.

[87] Rowe PN, Nienow AW, Agbim AJ. 1972. A preliminary quantitative study of particle segregation in gas fluidised bedsdbinary systems of near spherical particles. Trans. Inst. Chem. Eng. 50, 324-333.

[88] Chuang, S. Y., Dennis, J. S., Hayhurst, A. N., Scott, S. A., 2008. Development and performance of $\mathrm{Cu}$-based oxygen carriers for chemical-looping combustion. Combust. Flame. 154, 109-121.

[89] Imtiaz, Q., Kierzkowska, A. M., Broda, M., Müller, C. R., 2012. Synthesis of CuRich, $\mathrm{Al}_{2} \mathrm{O}_{3}$-Stabilized Oxygen Carriers Using a Coprecipitation Technique: Redox and Carbon Formation Characteristics. Environ. Sci. Technol. 2012, 46, 3561-3566.

[90] Garcia-Lario, A.L., Martinez, I., Murillo, R., Grasa, G., Fernandez, J. R., Abanades, J. C. 2013, Reduction Kinetics of a High Load Cu-based Pellet Suitable for $\mathrm{Ca} / \mathrm{Cu}$ Chemical Loops. Ind. Eng. Chem. Res. 52, 1481-1490.

[91] Sun, P., Grace, J. R., Lim, C. J., Anthony, E. J. 2007. The effect of CaO Sintering on Cyclic $\mathrm{CO}_{2}$ Capture in Energy Systems. AIChE, 53, 2432.

[92] Gonzalez, B., Grasa, G., Alonso, M., Abanades, J.C. 2008. Modeling of the Deactivation of $\mathrm{CaO}$ in a Carbonate Loop at High Temperatures of Calcination. Ind. Eng. Chem. Res. 47, 9256-9262

[93] Gecos, GS software, (2016). http://www.gecos.polimi.it/software/gs.php

[94] Grasa, G., Abanades, J. C., 2006. $\mathrm{CO}_{2}$ capture capacity of $\mathrm{CaO}$ in long series of carbonation/calcination cycles. Ind. Eng. Chem. Res. 45 (26) 8846-8851.

[95] Grasa, G., Murillo, R., Alonso, M., Abanades, J. C., 2009. Application of the random pore model to the carbonation cyclic reaction. AIChE J. 55 (5) 1246-1255.

[96] BREF-Cement, 2010. Lime and Magnesium Oxide Manufacturing Industries. European Commission, Brussels.

[97] Martínez, I., Grasa, G., Murillo, R., Arias, B., Abanades, J.C., 2012. Kinetics of Calcination of Partially Carbonated Particles in a Ca-Looping System for $\mathrm{CO}_{2}$ Capture. Energy and Fuels, 26, 1432-1440. 
[98] Martínez, I., Grasa, G., Murillo, R., Arias, B., Abanades, J.C., 2013. Modelling the continuous calcination of $\mathrm{CaCO}_{3}$ in a Ca-looping system. Chem Eng J. 215-216, 17418.

[99] Reh, L., 1995. New and efficient high-temperature processes with circulating fluid bed reactors. Chem. Eng. Technol. 18, 75-89.

[100] Abad, A., Adanez, J., Garcia-Labiano, F., de Diego, L.F., Gayan, P., 2010. Modelling of the chemical-looping combustion of methane using a $\mathrm{Cu}$-based oxygencarrier. Combustion and Flame, 157 (3) 602-615. 